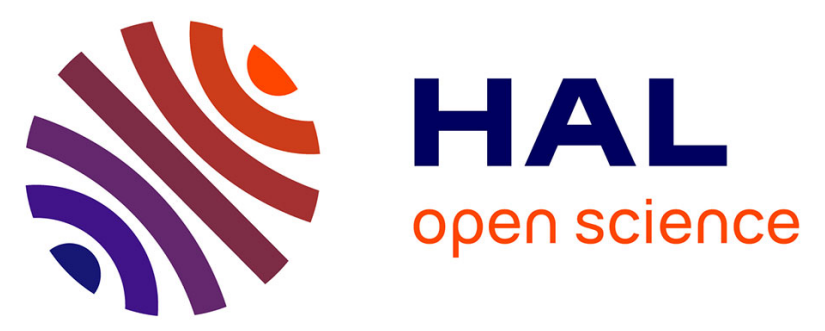

\title{
Crop processing, consumption and trade of Asian rice (Oryza sativa L.) in the Arabian Peninsula during Antiquity: earliest evidence from Mleiha (third c. AD), United Arab Emirates
}

Vladimir Dabrowski, Charlène Bouchaud, Margareta Tengberg, Michel Mouton

\section{To cite this version:}

Vladimir Dabrowski, Charlène Bouchaud, Margareta Tengberg, Michel Mouton. Crop processing, consumption and trade of Asian rice (Oryza sativa L.) in the Arabian Peninsula during Antiquity: earliest evidence from Mleiha (third c. AD), United Arab Emirates. Archaeological and Anthropological Sciences, 2021, 13. hal-03391779

\author{
HAL Id: hal-03391779 \\ https://hal.science/hal-03391779
}

Submitted on 28 Oct 2021

HAL is a multi-disciplinary open access archive for the deposit and dissemination of scientific research documents, whether they are published or not. The documents may come from teaching and research institutions in France or abroad, or from public or private research centers.
L'archive ouverte pluridisciplinaire HAL, est destinée au dépôt et à la diffusion de documents scientifiques de niveau recherche, publiés ou non, émanant des établissements d'enseignement et de recherche français ou étrangers, des laboratoires publics ou privés. 
Crop-processing, Consumption and Trade of Asian rice (Oryza sativa L.) in the Arabian Peninsula during Antiquity: Earliest Evidence from Mleiha ( ${ }^{\text {rd }}$ c. AD), United Arab Emirates

\author{
Vladimir Dabrowski ${ }^{1}$, Charlène Bouchaud ${ }^{1}$, Margareta Tengberg ${ }^{1}$, Michel Mouton ${ }^{2}$ \\ ${ }^{1}$ Archéozoologie, Archéobotanique : Sociétés, pratiques et environnements (UMR 7209), Muséum national \\ d'Histoire naturelle, CNRS \\ CP 56 - 55 rue Buffon, 75005 Paris (France) \\ vladimir.dabrowski@gmail.com (Corresponding author) \\ charlene.bouchaud@mnhn.fr \\ margareta.tengberg-mongne@mnhn.fr
}

${ }^{2}$ CNRS (IFPO), Beyrouth

MEAE-Liban - IFPO

13 rue Louveau, 92438 Châtillon Cedex (France)

m.mouton@ifporient.org

\begin{abstract}
Asian rice (Oryza sativa L.) was identified, among other plant remains, from several contexts in a fortified elite residence at the site of Mleiha (United Arab Emirates) that was partially destroyed by fire in the $3^{\text {rd }}$ century AD. These remains, present both as isolated grains and clusters of rice, constitute the earliest example of the species in the Arabian Peninsula and raise numerous questions on the role of rice in local economies during the Late PreIslamic period. The discussion focuses on two aspects of the finds. On the one hand the state of preservation and the archaeological contexts of the rice remains are investigated in detail in order to reconstruct crop processing activities that might have taken place within the building as well as different aspects of the preparation and consumption of what seems to have been a rare crop. On the other hand we discuss the origin of the Mleiha rice weighing the possible cultivation in local irrigated date palm gardens against its importation through the longdistance trade networks across the Persian Gulf and the Indian Ocean that are well attested by archaeological and textual sources for the period of concern.
\end{abstract}

\title{
Key-words
}

Asian rice; Arabian Peninsula; Antiquity; crop-processing; consumption; trade 


\section{Introduction}

Together with maize and wheat, rice is today among the most widely cultivated cereals in the world. It grows in more than 177 countries at latitudes ranging from $53^{\circ} \mathrm{N}$ to $35^{\circ} \mathrm{S}$ (Lu and Chang 1980) and at altitudes from $4 \mathrm{~m}$ b. s. 1. to $1500 \mathrm{~m}$ a. s. 1. (Nayar 2014: 1-8). The genus Oryza includes 20 wild species distributed in humid tropical and subtropical regions of Africa, Asia, Australia and America. Two species are domesticated: Asian rice (Oryza sativa L.), domesticated in East and South Asia and presently the most widely cultivated rice species in the world (Chang 2000: 133), and African rice (Oryza glaberrima Steud.) whose cultivation is restricted to Western Africa where its domestication took place (Agnoun et al 2012, Murray 2007). The wild ancestors of Asian rice are largely accepted to be the perennial Oryza rufipogon and the annual O. nivara, both present in South and South-East Asia today (Choi et al 2017, Sweeney and McCouch 2007, Londo et al 2006). Cultivated Asian rice varieties are traditionally divided into two categories, the short-grained japonica and the long-grained indica, although molecular research rather suggests the existence of five genetically distinct groups: aromatica, aus, indica, temperate japonica and tropical japonica (Garris et al 2005). Archaeobotanical and genetic studies have spread light on the domestication, diversification and diffusion processes of $O$. sativa in East and South Asia which have been the subject of much research and debate during the last decades (Güttaker et al 2019, Silva et al 2018, 2015, Choi et al 2017, Castillo et al 2016, Fuller et al 2016, 2010, Huang et al 2012, Fuller 2011, Sweeney and McCouch 2007).

On the contrary, rice spread to South-West Asia during historical times has received less attention. Textual references mention diffusion of rice cultivation and consumption in South-West Asia, particularly in Susiana and Mesopotamia, from the $1^{\text {st }}$ millennium BC. The only archaeobotanical evidence so far consisted of 373 grains of rice on a storage room floor dated to the $1^{\text {st }} \mathrm{c}$. AD in the Ville Royale II in Susa (Miller 1981) as well as ricehusk impressions on mud bricks from several sites in the South Dez plain of Susiana in Iran, dated from 25 BC to $250 \mathrm{AD}$, what indicate that rice was locally grown in this region during this period (Miller 2011). Furthermore, rice has been found in the Roman harbours of Berenike (Cappers 2006: 104-105) and Myos Hormos (Van der Veen 2011: 46-48) in the Eastern Desert of Egypt, mostly in form of spikelets and husk fragments, as well as in the Roman fort of Didymoi in the form of a single spikelet (Tengberg 2011). Together with other imported goods and commodities, these discoveries show the importance of the Egyptian Red Sea shore in long-distance trade within the Indian Ocean at least from the $1^{\text {st }}$ century AD (Seland 2014: 380-383, Tomber 2012, 2008: 71-87, Warmington 1928: 6-8).

The recent discovery of rice at the Late Pre-Islamic site of Mleiha in the Emirate of Sharjah (United Arab Emirates, UAE), constitutes the earliest evidence of the presence of this crop in the Arabian Peninsula. Archaeological, epigraphic and numismatic evidence suggest regional tribal-base social organization to the scale of the Oman peninsula with Mleiha acting as central political authority under the rule of a "king of Oman" (Overlaet et al 2016, Mouton and Schiettecatte 2014, Mouton 2010). Long-distance trade evidence is attested since the beginning of the occupation of the site showing connections with Mesopotamia, Iran, the eastern Mediterranean area and the Indian sub-continent (Mouton and Schiettecatte 2014, Mouton 2010, Benoist et al 2003). 
The discovery of Asian rice underlines the integration of Mleiha into long-distance trade networks along with other archaeological artifacts and raises questions about its use and origin. Nevertheless, it is necessary to better understand this rice findings in order to determine the extent of this discovery. It is important to know if rice was just considered as a traded merchandise or it was consumed by the inhabitants of the building, and if so in what form, for questioning their cultural identity as well as defining introduction of new crop-processing and consumption practices. We can also ask rice was imported from elsewhere, and if so from where, or alternatively its presence can be explained by local cultivation. The question of its origin is particularly crucial because importation would indicate rice trade circulation within the Indian Ocean while acclimatization involves also socio-ecological upheavals within local agricultural systems. After a description of the finds and their archaeological context, we consider the Mleiha rice remains in the light of the social, economic and agronomic conditions of the $3^{\text {rd }}$ century AD Oman Peninsula in order to provide new insights into the consumption and diffusion of this cereal in Eastern Arabia during the Classical period.

\section{The site of Mleiha}

Mleiha is situated in the Oman peninsula, $10 \mathrm{~km}$ west of the el-Hajar Mountains (Fig. 1). The climate is arid with summer temperatures reaching more than $45^{\circ} \mathrm{C}$ and an annual rainfall that does not exceed $100 \mathrm{~mm}$ (Sanlaville 2000: 49, 55, Boer 1997). Seasonal rivers or wadis appear during the rainy season, including the two major ones Wadi Nayassa and Wadi Niyam, that run down into the plain from the nearby mountains. Despite the aridity, the presence of subterranean water resources as well as fertile loam deposits provide favourable conditions for agriculture and allow the presence of extended date palm groves in the plain (Dalongeville 1999). The present vegetation cover around the site is characterised by a pseudo-savannah dominated by Prosopis cineraria, known locally as the ghaf tree, and Hammada elegans shrubs on sandy soils. The gravel plain stretching towards the Oman Mountains is characterised by open thorn shrublands with Acacia tortilis, Ziziphus spina-christi, Rhazya stricta, Gymnocarpos decandrum and Jauberta aucheri (Tengberg 2008, Sainz Ollero and Carcia Anton 1999).

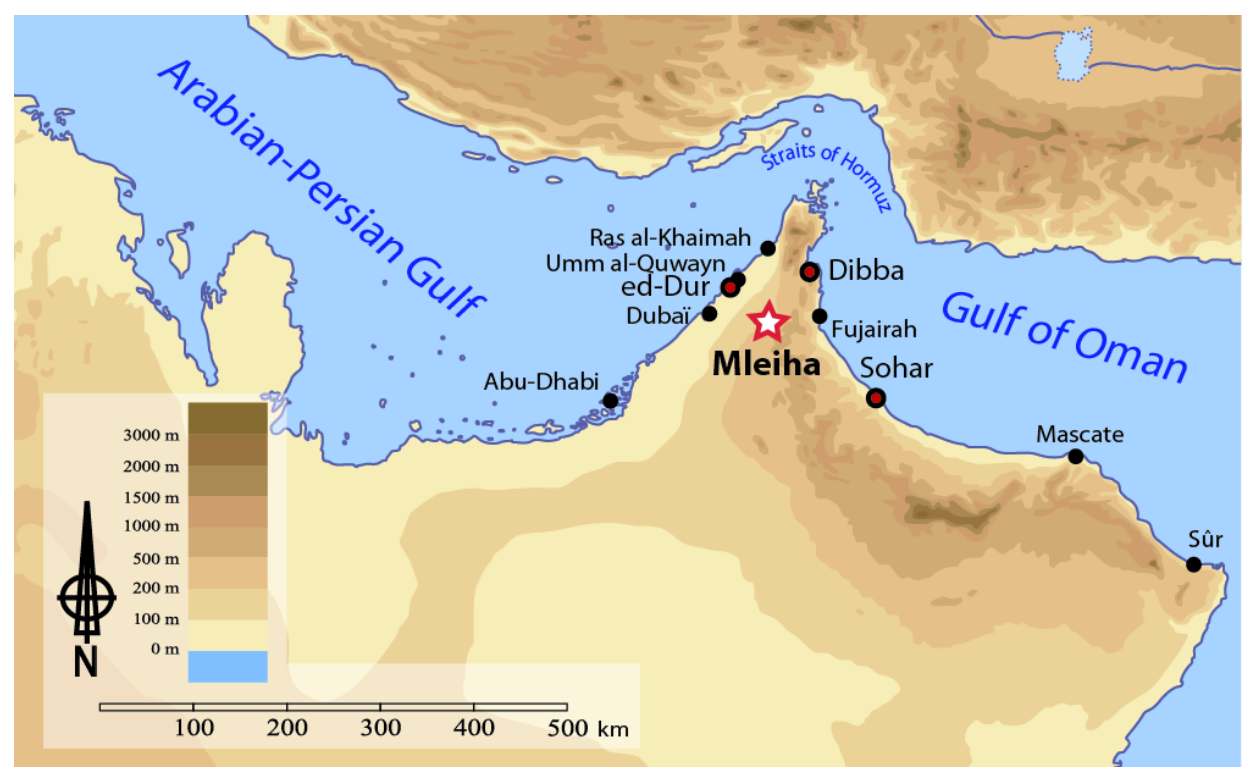

Figure 1: Localization of Mleiha (star), others contemporaneous sites (red dots) and modern towns (black dots) (map background: H. David, IFPO) (This figure should be in color). 
Excavations have been carried out at Mleiha by the French Archaeological Mission in the UAE between 1986 and 2011, successively under the direction of R. Boucharlat and M. Mouton (CNRS, France). Its occupation dates from the $3^{\text {rd }}$ century $\mathrm{BC}$ to the middle of the $3^{\text {rd }}$ century $\mathrm{AD}$ and belongs to the Late Pre-Islamic period (PIR) (Mouton and Schiettecatte 2014, Mouton 2010). The spatial pattern and evolution of the settlement can be compared to those of recently sedentarized nomadic tribes and suggests that the site was first settled by mobile populations (Mouton and Schiettecatte 2014, Mouton 2010, Mouton 1999b). Archaeological material such as stamped Rhodian amphorae handles dated to the $3^{\text {rd }}-2^{\text {nd }}$ centuries BC reflects the integration of the site in longdistance trade networks since the earliest phase (Mouton et Schiettecatte 2014, Mouton 2010, Mouton 2008: 4049). The volume of imported goods including foreign potteries (Roman Skyphos handled cups, Torpedo jars), blown glass vessels and numerous coins from Mesopotamia, Levant and the Gulf Region increases from the beginning of the Christian era (Mouton and Schiettecatte 2014, Mouton 2010, Mouton 2008: 94-117), particularly during the last phase of occupation, from the mid- $2^{\text {nd }}$ century AD to the mid- $3^{\text {rd }}$ century AD. A wide array of foreign potteries and luxury goods then highlight long-distance trade patterns ranging from the Mediterranean basin to the Indian sub-continent including Mesopotamia and Iran (Benoist et al 2003). In parallel, the apparition of fortified residences, such as the building H (Figs. 2 and 3-A), reveals a regional context of increasing insecurity. The partial destruction of some of these buildings and their apparently sudden abandonment in the first half of the $3^{\text {rd }}$ century $\mathrm{AD}$ is a possible consequence of the military campaign led by the Sasanian king Ardashir in the Persian Gulf around 240 AD (Mouton and Schiettecatte 2014, Mouton 2010, Cuny et Mouton 2009).

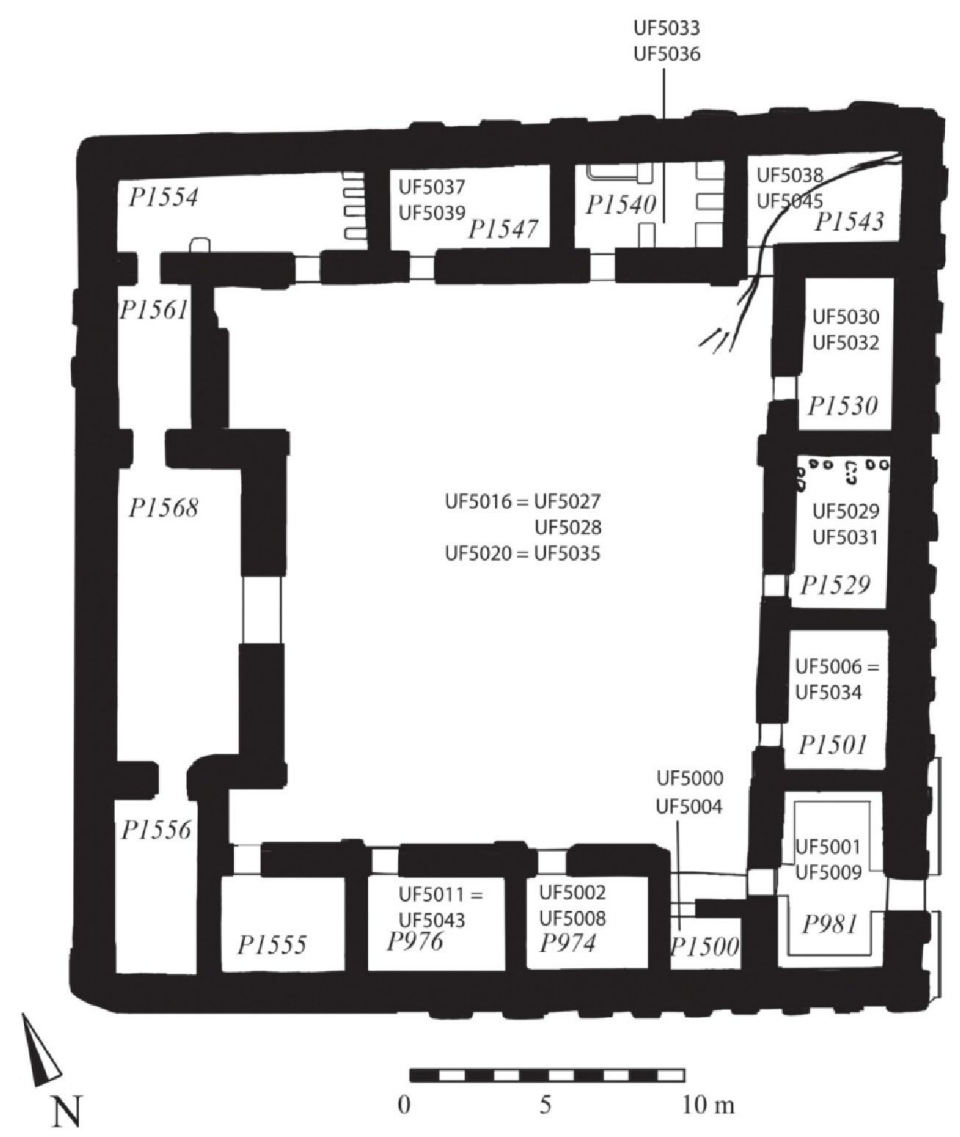

Figure 2: General plan of the building H (C) French Archaeological Mission of the UAE). 

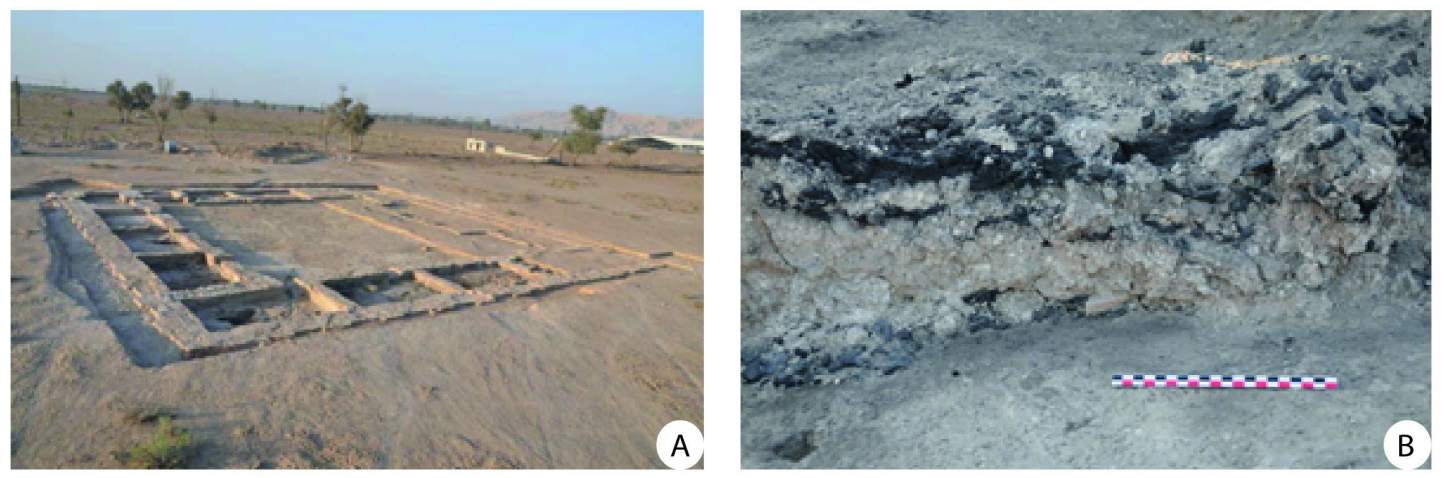

Figure 3: Building H during excavations (A: View from the North-East; B: The fire destruction layer) (C) French Archaeological Mission of the UAE).

The botanical assemblages described in this paper come from the fortified building H located in the north-eastern part of the site and dated to the final phase of occupation. It was partially excavated by an Iraqi team during the 1970s (Madhloom 1974) before being completely cleared by the French mission in 2010-11 (Mouton et al 2012). An outer defensive mud-brick wall flanked by towers encloses a central mud-brick building. The latter is almost square $(32 \mathrm{~m} \times 30 \mathrm{~m})$ and comprises 15 rooms distributed around a central courtyard. A unique entrance door at the south-eastern corner gave access to what seems to be a guards' room with benches (P981). The precise function of all rooms could not be set but the spatial organisation and the finds distribution suggest that the building included storage facilities (P1529, P974?), a kitchen (P1540) and a domestic area (P1547). The thickness of the walls as well as the stratigraphy of the destruction layers indicate the presence of an upper floor probably hosting the living quarters. A wide array of pottery types has been recovered among which imported wares are largely predominant (>83\%), glazed pottery from southern Mesopotamia (42\%) and cooking pots and globular jars from the Indo-Pakistani region (28\%) being particularly well represented. This large multi-room fortified residence containing luxury goods such as glass vessels, golden jewellery, ivory objects from longdistance trade was certainly related to local elite. Its destruction by fire (Fig. 3-B) and the presence of numerous iron arrowheads as well as the apparent loss of luxury goods, probably grasped in a hurry, indicate that a dramatic event was the cause of the building's sudden abandonment.

The fire accounts for an exceptional conservation, by charring, of organic remains such as seeds, fruits and wood fragments as well as whole or partial wooden artefacts, textiles, basketry and ropes. Most of these were found in situ, that is where they were left by the inhabitants, and were retrieved manually during excavation. Nine sediment samples, corresponding to a total volume of 900 litres, were further collected and carbonised plant remains were extracted from these by manual bucket flotation using a sieve with a mesh-size of $0.5 \mathrm{~mm}$.

The seed and charcoal remains from building $\mathrm{H}$ have been the subject of a preliminary study carried out by $\mathrm{M}$. Tengberg and D. Soulié (Mouton et al 2012). The results presented here are part of a more detailed analysis of archaeobotanical and archaeoentomological assemblages (Dabrowski 2019). 
The rice remains only represent a minor part of the total plant assemblage that consists, on the one hand, of isolated seed and fruit remains and, on the other, of clusters of seeds and/or fruits, fused together during burning. The latter probably correspond to concentrations of food products stored in different types of containers of which some have been identified (woven bags, baskets) (Kerfant 2015).

The diversity of the plant taxa identified from building $\mathrm{H}$ at Mleiha is unusually high for Eastern Arabia where the conservation of organic remains is often mediocre. The remains of annual crops of temperate origin such as hulled barley (Hordeum vulgare), free-threshing wheat (Triticum aestivum/durum), lentil (Lens culinaris) and grass pea (Lathyrus sativus) are common. Fruit species such as date palm (Phoenix dactylifera), grapevine (Vitis vinifera), pomegranate (Punica granatum) and almond (Prunus sp.) are also attested (Mouton et al 2012). Many of the identified crops may have been cultivated locally in irrigated date palm gardens attested in the Oman Peninsula since the $3^{\text {rd }}$ millennium BC (Tengberg 2012). At Mleiha, such gardens were probably located in the loamy lower part of the alluvial plain (Dalongeville 1999; Peña-Chocarro and Barrón Lopez 1999).

The whole archaeobotanical assemblage found in the building has been dated by a combination of ceramic evidence and AMS dating. The pottery assemblage corresponds to the general occupation phase D of the site (PIR-D), dated mid- $2^{\text {nd }}$ c.-mid. $3^{\text {rd }}$ c. AD. In this particular building, in the destruction level, the presence of one amphora Käpitan 2 which is mostly found from Italy to Britain during the $3^{\text {rd }}-4^{\text {th }} \mathrm{c}$. AD allow to date the fire destruction of the building not before the $3^{\text {rd }} \mathrm{c}$. AD (Mouton et al 2012). In addition, three AMS dating have been obtained with three whole grape fruits from the fire destruction levels of the building which allow to date its burning down between the end of the $1^{\text {st }} \mathrm{c}$. AD and the mid- $3^{\text {rd }} \mathrm{c}$. AD. Supplementary dating has been realized on textile pieces and have provided consistent dates with the previous ones. All these dates are in the process of being published (Ryan et al, submitted). The building was not reoccupied after so the risks of contamination are considered as none and we assume that the whole archaeobotanical material corresponds to material left behind by the inhabitants during the fire. Moreover, the nature and number of rice remains suggest that they well belong to the material preserved by fire which destroyed the building. On the basis of these elements, we can assume that the fire of the building and the carbonized material preserved in the destruction layer dates back to the $1^{\text {st }}$ half of the $3^{\text {rd }}$ c. AD.

\section{Description of the rice remains}

Asian rice (Oryza sativa L.) has been found in six hand-picked and four sediment samples recovered from seven destruction fire levels (SU) from four different rooms and the courtyard (for precise contexts, see tables 1 and 2). The majority of the hand-picked samples consist of clusters of rice grains, sometimes associated with the remains of other taxa (Figs. 4 and 5).

The rice remains were studied with the help of a binocular stereomicroscope (Nikon SMZ645) in the archaeobotanical laboratory at the National Museum of Natural History in Paris (UMR 7209). Their identification was based on criteria found in the scientific literature (Fuller and Castillo 2014, Fuller and Qin 
2008) and by comparison with specimens in a modern reference collection. The rice grain (botanically a fruit called caryopsis) is more or less elongated and laterally compressed with longitudinal ridges and a short embryo. The inner glumes (lemma and palea) that enclose the grain are identified by the regular and reticular ornamentation of their surface corresponding to the presence of double-picked phytoliths (Fuller and Castillo 2014). Immature grains were occasionally noted among the remains due to their smaller size and sharp "papery" edges (Fuller and Qin 2008). In some cases, whole rice spikelets had been preserved more or less intact with both their inner glumes and the smaller outer glumes inserted at the upper part of the rachis segment.

\section{Isolated rice grains}

Among the isolated rice remains, recovered either manually during excavation or from the flotation residue, both whole grains and fragments were present (Tab. 1). They have been found in three different rooms $(1500,1529$, and 1540) and in the courtyard. In order to estimate the original number of grains or "Minimum Number of Individuals" (MNI) we have divided the total number of fragments from each sample by two. Using this mode of calculation, we registered a total number of 310 individual rice caryopses (148 whole and 322 fragments), including one immature caryopsis.

\section{Rice clusters}

Most of the rice remains from Mleiha are found in the form of clusters of grain of varying sizes (Tab. 2; for more details, see tab. 1 as Electronic Supplementary material). A total of 161 such clusters have been collected, most of them ( $\mathrm{N}=143)$ from $\mathrm{P} 1540$, a room interpreted as a kitchen due to the presence of cooking pots and specific installations related to the preparation of food. 15 supplementary clusters of grain were found in the courtyard, two from the room 1500 situated near the entrance and a single one from the room 974. At a first glance these organic remains seem amorphous but close observation allows the identification of rice grains and husks and, in some cases, whole spikelets. The presence of these different elements was registered for each cluster as well as the proportion of whole grains versus fragmented ones and the general state of the grains. Particular attention was paid to the interior of broken grains that tends to be more compact when well preserved and of alveolar aspect when heavily burnt. The number of rice elements forming each cluster could not be precisely counted but was evaluated using a scale from 1 to 4 ( $1=1-5$ items; $2=6-10 ; 3=11-20 ; 4=>20)$.

Chaff remains are rare in the rice clusters, especially those found in room P1540. Only one whole and five fragmentary spikelets were observed on a total of six clusters and fragmentary husks were seen on 16 usually on lumps with few rice remains. Although carbonisation may have destroyed part of these fragile elements (Boardman and Jones 1990), rice husks are more robust than those of other cereals and thus liable to better resist fire (Harvey and Fuller 2005). Their scarcity in our samples suggests that the rice had been cleaned prior to carbonisation. On the contrary, the rice clusters from the courtyard contain more chaff remains and may correspond to not yet entirely clean grain (see the discussion below). Further, the remains from the courtyard seem in general less well preserved (interior structure of grains alveolar) and this is also the case for the organic clusters found in the rooms P974 and P1500. 


\section{Taxa associated with the rice remains}

Other plant elements present in the organic clusters or in sediment samples associated with rice remains have been also recorded. Their quantity has been evaluated in the same way as the rice elements. Two millets of Indian origin are recurrently attested associated both with isolated grains (either hand-picked or extracted by flotation) and with the clusters. They both belong to the Panicoidae subfamily of grasses (Poaceae): kodo millet (Paspalum scrobiculatum) and little millet (Panicum cf. sumatrense) and appear in the form of grains either cleaned or still enclosed in their husks. Some of the grains seem immature. The Kodo millet grain is nearly round in plan, has a linear hilum and the length of the scutellum is less than half of the grain. The pericarp surface is characterised by a polygonal cellular pattern. The grain of small millet is ovate with an apex slightly pointed. The scutellum is shallow and attains more or less the middle of the grain (Fuller 2017) (Figure 4).

Millet remains are recorded from 111 organic rice clusters. Kodo millet has been observed on 107 of them mostly in low quantities. They are mainly present in the form of grains still entirely or partially enclosed in their husks (46\% of organic clusters) or as husk fragments only (36\%). Small quantities of little millet are recorded from 19 organic clusters, in the form of grains still entirely or partially enclosed in their husks.

The two millets are commonly infesting modern rice fields (Rao et al 2017, 2007, Weisskopf et al 2014, Moody 1989: 63-64, Galinato 1999: 92, de Wet 1983a, b) and when found in archaeological contexts they are commonly interpreted as weeds (Fuller 2011b). This also seems to be the most plausible explanation for their presence at Mleiha. 
A
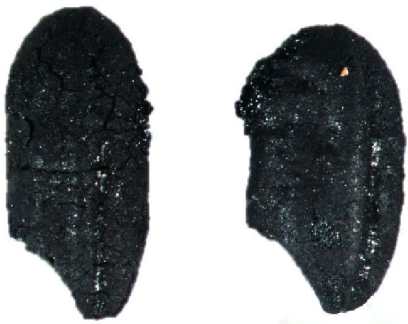

$2 \mathrm{~mm}$

$\mathrm{D}$
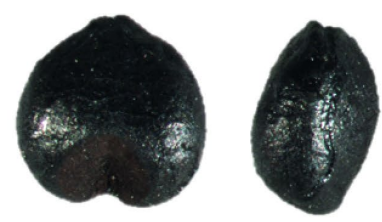

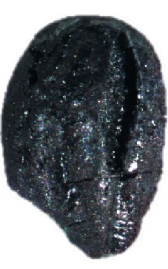

$1 \mathrm{~mm}$
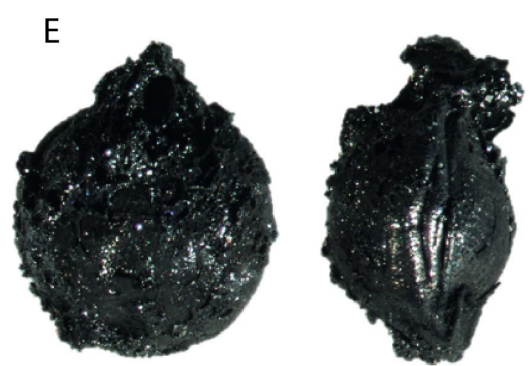

$1 \mathrm{~mm}$

$\mathrm{H}$

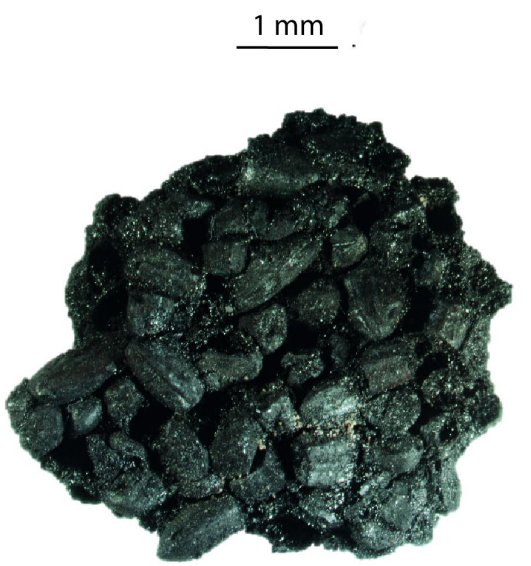

B

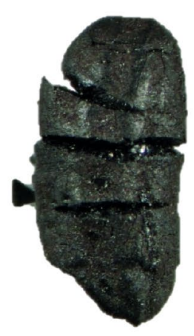

C

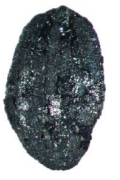

$2 \mathrm{~mm}$

$1 \mathrm{~mm}$

$\mathrm{F}$

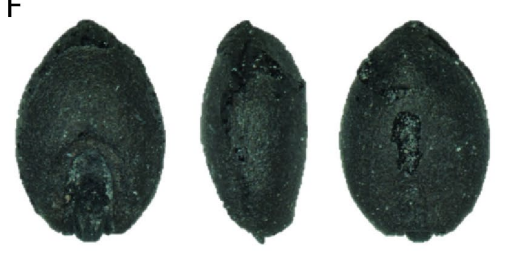

$1 \mathrm{~mm}$

G

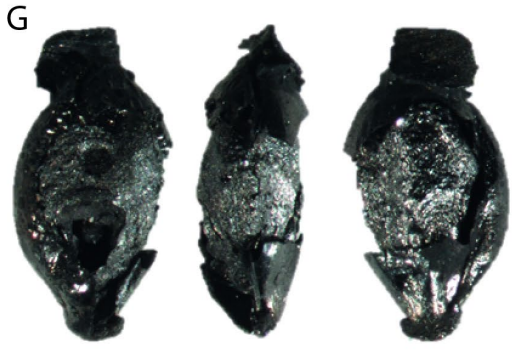

$1 \mathrm{~mm}$

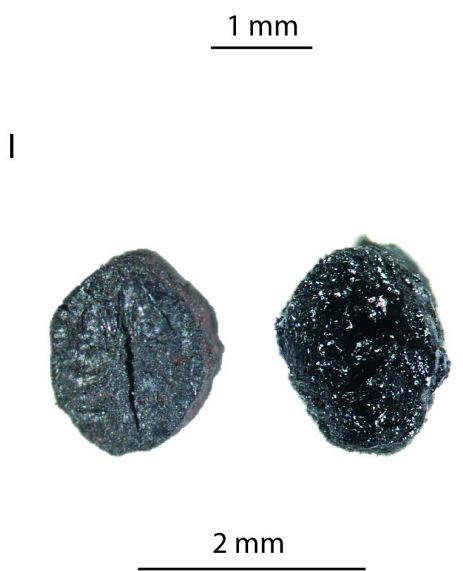

$5 \mathrm{~mm}$

Figure 4: Seed remains from building H. A: Three grains of Asian Rice (Oryza sativa L.) in lateral view; B: Rice grain with apparent fissures in lateral view; C: Immature rice grain in lateral view; D-E: Kodo millet (Paspalum scrobiculatum L.) grain in dorsal, lateral and ventral view from left to right, free (D) and still hulled (E) ; F-G: Little millet (Panicum cf. sumatrense) grain in dorsal, lateral and ventral view from left to right, free (F) and still hulled $(\mathrm{G})$; H: Organic clusters with agglomerated grains corresponding mostly to broken rice grains; I: Transverse section of rice grain with compact (left) and alveolar (right) inside. 

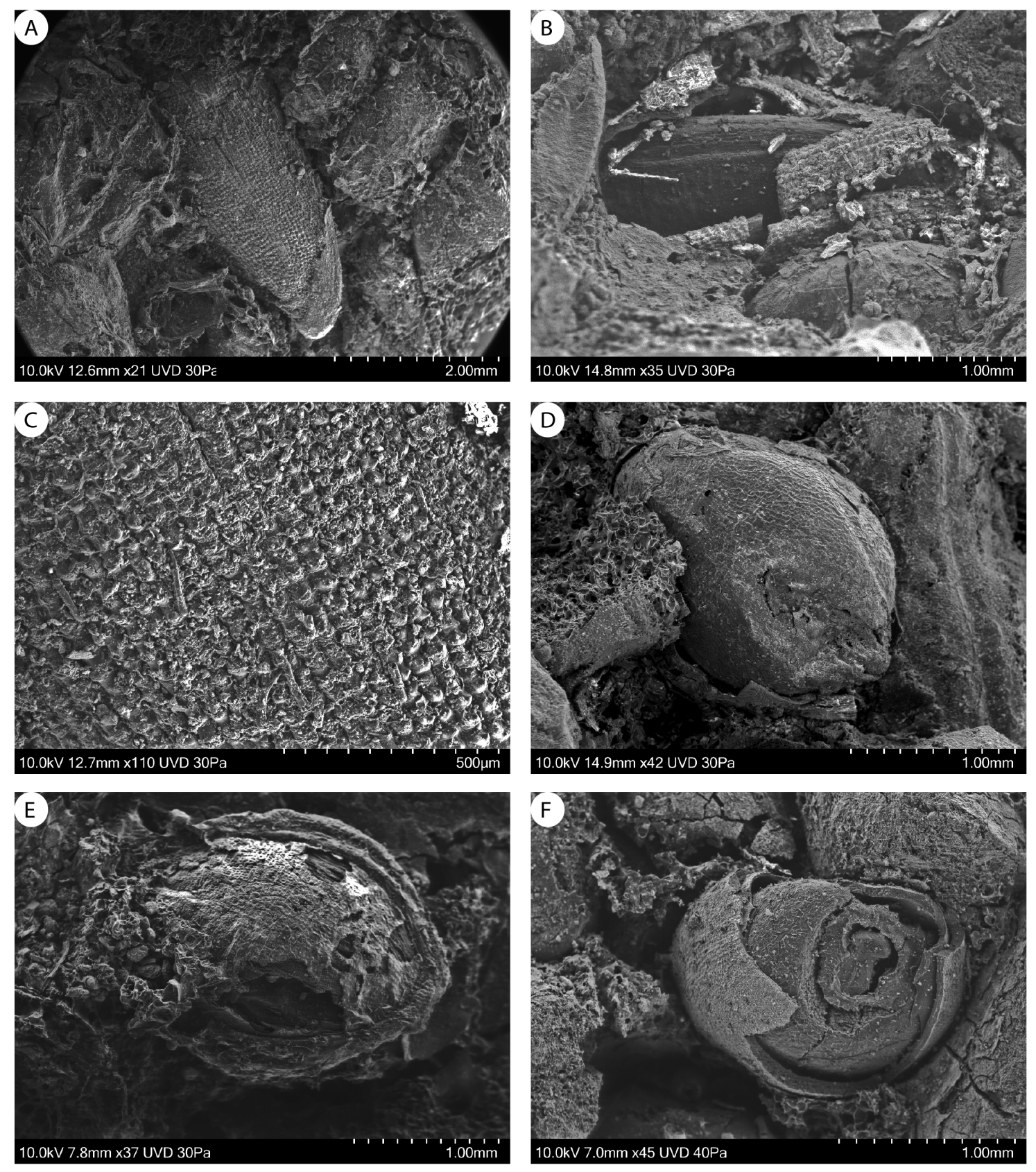

Figure 5: Details of organic clusters found at Mleiha, building H, SEM photographs. A: Whole rice spikelet; B: Rice grain still partially enclosed in its husk; C: details of rice husk surface (lemma and palea) with the doublepicked phytoliths organized in regular pattern; D: Grain of little millet still partially hulled; E-F: Grain of kodo millet totally (E) or partially (F) hulled. 
Table 1: Details of free grains finds ( $\mathrm{SU}=$ Stratigraphic Unit; HP= hand-picked samples; $\mathrm{S}=$ Sediment samples; NR=Number of Remains, MNI=Minimum Number of Individuals).

\begin{tabular}{|c|c|c|c|c|c|c|c|c|c|c|c|c|c|c|c|c|c|c|c|}
\hline & Room & \multirow{2}{*}{\multicolumn{2}{|c|}{$\begin{array}{l}1500 \\
5004\end{array}$}} & \multicolumn{4}{|c|}{1529} & \multicolumn{8}{|c|}{1540} & \multirow{3}{*}{\multicolumn{2}{|c|}{$\begin{array}{c}\text { Courtyard } \\
5027 \\
10.140\end{array}$}} & \multicolumn{2}{|c|}{ Total } \\
\hline & UF & & & \multicolumn{2}{|c|}{5029} & \multicolumn{2}{|c|}{5031} & \multicolumn{2}{|c|}{5033} & \multicolumn{6}{|c|}{5036} & & & & \\
\hline & Sample & \multicolumn{2}{|c|}{10.008} & \multicolumn{2}{|c|}{10.110} & \multicolumn{2}{|c|}{10.111} & \multicolumn{2}{|c|}{10.120} & \multicolumn{2}{|c|}{10.143} & \multicolumn{2}{|c|}{10.151} & \multicolumn{2}{|c|}{10.152} & & & & \\
\hline & Type of sample & \multirow{2}{*}{\multicolumn{2}{|c|}{$\begin{array}{c}\mathrm{S} \\
49\end{array}$}} & \multicolumn{2}{|c|}{$\mathrm{S}$} & \multicolumn{2}{|c|}{$\mathrm{S}$} & \multicolumn{2}{|c|}{$\mathrm{S}$} & \multicolumn{2}{|c|}{ HP } & \multicolumn{2}{|c|}{$\mathrm{S}$} & \multicolumn{2}{|c|}{$\mathrm{HP}$} & \multicolumn{2}{|c|}{ HP } & & \\
\hline \multirow{2}{*}{\multicolumn{2}{|c|}{ Vol. (I.) }} & & & \multicolumn{2}{|c|}{50} & \multicolumn{2}{|c|}{240} & \multicolumn{2}{|c|}{56} & & & & 88 & & - & & & & \\
\hline & & \multicolumn{2}{|c|}{\begin{tabular}{l|l} 
NR & MNI
\end{tabular}} & NR & MNI & NR & MNI & NR & MNI & NR & MNI & NR & MNI & NR & $\mathrm{MNI}$ & NR & MNI & $\mathrm{NR}$ & MNI \\
\hline & Whole grain & 1 & 1 & - & - & - & - & - & - & 133 & 133 & - & - & 7 & 7 & 6 & 6 & 147 & 147 \\
\hline Oryza sativa & Fragment of grain & - & - & - & - & 1 & 1 & - & - & 303 & 152 & - & - & 12 & 6 & 6 & 3 & 322 & 162 \\
\hline & Immature grain & 1 & 1 & - & - & - & - & - & - & - & - & - & - & - & - & - & - & 1 & 1 \\
\hline Panicum cf. & Whole hulled grain & - & - & - & - & - & - & - & - & - & - & 1 & 1 & - & - & - & - & 1 & 1 \\
\hline & Immature grain & - & - & - & - & - & - & - & - & - & - & 2 & 2 & - & - & - & - & 2 & 2 \\
\hline & Whole grain & - & - & - & - & - & - & - & - & 19 & 19 & 1 & 1 & 8 & 8 & - & - & 28 & 28 \\
\hline & Fragment of grain & - & - & - & - & - & - & 1 & 1 & - & - & 1 & 1 & - & - & - & - & 2 & 2 \\
\hline $\begin{array}{c}\text { Paspalum } \\
\text { scrobiculatum }\end{array}$ & Immature grain & - & - & - & - & - & - & - & - & - & - & 3 & 3 & - & - & - & - & 3 & 3 \\
\hline & Whole hulled grain & - & - & - & - & - & - & - & - & 11 & 11 & 1 & 1 & 11 & 11 & - & - & 23 & 23 \\
\hline $\begin{array}{c}\text { cf. Paspalum } \\
\text { scrobiculatum }\end{array}$ & Whole grain & 1 & 1 & - & - & - & - & - & - & - & - & - & - & - & - & - & - & 1 & 1 \\
\hline Total & & 4 & 4 & 2 & 2 & 7 & 7 & 1 & 1 & 469 & 318 & 18 & 18 & 38 & 32 & 12 & 9 & 539 & 382 \\
\hline
\end{tabular}


Table 2: Details of organic clusters analysis. The table includes the number of rice clusters in which each type of remains is attested and for each category of the quantitative system. The organic clusters from the rooms 974 and 1500 have not been presented here because of their very low quantity and their bad state of preservation. (HP= handpicked samples; ?: Organic clusters too badly preserved to be described with details; T: Total)

\begin{tabular}{|c|c|c|c|c|c|c|c|c|c|c|c|c|c|c|c|c|c|c|c|c|c|c|c|c|c|c|c|}
\hline & Room & \multicolumn{13}{|c|}{ P1540 } & \multicolumn{13}{|c|}{ Courtyard } \\
\hline & SU & \multicolumn{13}{|c|}{5036} & \multicolumn{13}{|c|}{5027} \\
\hline & Sample & \multicolumn{13}{|c|}{$10.143+10.152$} & \multicolumn{13}{|c|}{$10.142+10.163$} \\
\hline & Type of sample & \multicolumn{13}{|c|}{$\mathrm{HP}$} & \multicolumn{13}{|c|}{$\mathrm{HP}$} \\
\hline & Total number of clusters & \multicolumn{13}{|c|}{143} & \multicolumn{13}{|c|}{15} \\
\hline & Quantitative system & 0 & $\%$ & 1 & $\%$ & 2 & $\%$ & 3 & $\%$ & 4 & $\%$ & $?$ & $\%$ & $\mathrm{~T}$ & 0 & $\%$ & 1 & $\%$ & 2 & $\%$ & 3 & & 4 & $\%$ & ? & $\%$ & $\mathrm{~T}$ \\
\hline \multirow{8}{*}{$\begin{array}{c}\text { Asian Rice } \\
\text { (Oryza sativa) }\end{array}$} & Abundance & - & - & 36 & 25 & 9 & 6 & 32 & 22 & 36 & 25 & 30 & 21 & 143 & - & - & - & - & - & - & 1 & & 5 & 33 & - & - & 15 \\
\hline & Quantity of grains & 6 & 5 & 30 & 27 & 9 & 8 & 32 & 28 & 36 & 32 & - & - & 113 & - & - & - & - & - & - & 1( & & 5 & 33 & - & - & 15 \\
\hline & Whole grains & 17 & 15 & 74 & 65 & 16 & 14 & 4 & 4 & 2 & 2 & - & - & 113 & 1 & 7 & 2 & 13 & 9 & 60 & 3 & & - & - & - & - & 15 \\
\hline & Fragmented grains & 38 & 34 & 9 & 8 & 12 & 11 & 35 & 31 & 19 & 17 & - & - & 113 & - & - & - & - & 7 & 47 & 8 & & - & - & - & - & 15 \\
\hline & Alveolar inside & 38 & 34 & 63 & 56 & 10 & 9 & 2 & 2 & - & - & - & - & 113 & - & - & - & - & 6 & 40 & 8 & & 1 & 7 & - & - & 15 \\
\hline & Compact inside & 42 & 37 & 23 & 20 & 15 & 13 & 21 & 19 & 12 & 11 & - & - & 113 & 13 & 87 & 2 & 13 & - & - & - & & - & - & - & - & 15 \\
\hline & Spikelets & 107 & 95 & 6 & 5 & - & - & - & - & - & - & - & - & 113 & 12 & 80 & 3 & 20 & - & - & - & & - & - & - & - & 15 \\
\hline & Fragments of husk & 97 & 86 & 16 & 14 & - & - & - & - & - & - & - & - & 113 & 4 & 27 & 11 & 73 & - & - & - & & - & - & - & - & 15 \\
\hline \multirow{4}{*}{$\begin{array}{l}\text { Kodo millet } \\
\text { (Paspalum } \\
\text { scrobiculatum) }\end{array}$} & Abundance & 36 & 25 & 77 & 54 & 9 & 6 & 2 & 1 & - & - & 19 & 13 & 143 & 13 & 87 & 2 & 13 & - & - & - & & - & - & - & - & 15 \\
\hline & Hulled grains & 36 & 29 & 46 & 37 & 5 & 4 & - & - & - & - & - & - & 124 & 13 & 87 & 2 & 13 & - & - & - & & - & - & - & - & 15 \\
\hline & Dehulled grains & 36 & 29 & 7 & 6 & - & - & - & - & - & - & - & - & 124 & 15 & 100 & - & - & - & - & - & & - & - & - & - & 15 \\
\hline & Fragments of husk & 36 & 29 & 32 & 26 & 5 & 4 & 1 & 1 & - & - & - & - & 124 & 15 & 100 & - & - & - & - & - & & - & - & - & - & 15 \\
\hline \multirow{2}{*}{$\begin{array}{l}\text { Little millet } \\
\text { (Panicum cf. } \\
\text { sumatrense) }\end{array}$} & Abundance & 123 & 86 & 14 & 10 & - & - & - & - & - & - & 6 & 4 & 143 & 15 & 100 & - & - & - & - & - & & - & - & - & - & 15 \\
\hline & Hulled grains & 123 & 90 & 14 & 10 & - & - & - & - & - & - & - & - & 137 & 15 & 100 & - & - & - & - & - & & - & - & - & - & 15 \\
\hline
\end{tabular}




\section{Crop processing and consumption of rice remains}

The fire that partly destroyed building $\mathrm{H}$ allowed the preservation of the rice assemblages described above in situ and, according to their nature and location, they may correspond to different stages of the cleaning and preparation of the crop prior to storage or consumption. Ethno-archaeological studies based on non-mechanized traditional Asian rice crop-processing activities can be useful in order to propose a reconstruction of the activities related to rice within the building.

\section{Possible dehulling of rice in the courtyard}

The threshing of harvested rice allows the separation of straw and panicles on the one hand and the breaking of panicles into spikelets on the other. Winnowing then separates the spikelets from the light threshing by-products consisting mainly of fragmented straw. The subsequent sieving of the winnowing product produces assemblages of more or less pure grain but in which the caryopses are still enclosed in their husks. These first steps of the post-harvest treatment of rice usually take place outdoors, often on special threshing floors near fields or villages (Castillo 2018, Thompson 1996).

Before being consumed, the rice needs a second round of cleaning in order to eliminate the indigestible glumes and this step is traditionally carried out with the help of a pestle and mortar or with a grindstone (Castillo 2018, Thompson 1996). In the building $\mathrm{H}$ at Mleiha grindstones made of diorite and sandstone may have served such a purpose. The dehulling process results in clean grains that are brown in colour ("brown rice"), due to the persistence of the pericarp, and, as a by-product, fragmentary glumes, spikelet bases and occasional remains of straw, whole or fragmented spikelets and broken grains, or weeds (Fig. 7). The dehulling by-product is separated from the clean grain by a second winnowing, followed by one or several sievings. The dehulling of rice, as well as other hulled cereal species, is traditionally carried out piecemeal and in direct relation to food preparation, usually within the household, and shortly before consumption (Castillo 2018, Abe 2007, 69-70).

The clusters of rice found in the courtyard (Tab. 2) are mainly composed of whole and fragmentary grains associated with a low number of spikelets, husk fragments and millets and may correspond to an assemblage of rice that had been cleaned already or was in the last stages of dehulling. It is not excluded that the final cleaning of rice took place within the building and in particular in the courtyard, even though the proportion of fragmented husks is rather low. It should be noted though that these fragile elements are unlikely to survive heavy burning.

The breakage of rice grains: intentional or accidental?

The bulk of rice remains is found in the room interpreted as a kitchen (P1540) and there is no reason to doubt that the grains present there, together with other foodstuffs and cooking pots, were intended for human food. The close examination of the numerous clusters from this room shows a high proportion of broken grains and we may ask if this breakage was first prior to carbonization and if so, whether it was intentional or accidental. 
In order to answer this first issue, we carried out correspondence analysis (CA) on the quantity and aspect of rice grains in the organic clusters from the kitchen P1540 in order to describe and compare the numerous lumps. The dataset includes 107 samples $^{1}$ and 5 variables: number of grains (according to the scale described above); number of whole grains; number of fragmented grains; interior structure (compact or alveolar). The analysis (Fig. 6; for more details, see tables 2-5 as Electronic Supplementary material) shows a high contribution on the two first axes ( $84 \%$ of the total variance). The negative part of the factor 1 groups organic clusters with numerous broken grains presenting rather compact inside and the positive part associates samples with low quantities of whole and alveolar rice grains. In other words, the set in the negative part highlight correlations between the numerous broken rice grains with the interior compact structure. As this type of interior suggests that the archaeological material is well-preserved, we can assume that they may have been broken before the fire building. Besides, this affirmation can be supported by new experimentations which have shown that cleaned grains would be better preserved if they are burnt as lumps rather than isolated grains without any protection (Castillo 2018) since numerous broken grains have been found grouped together on each cluster.

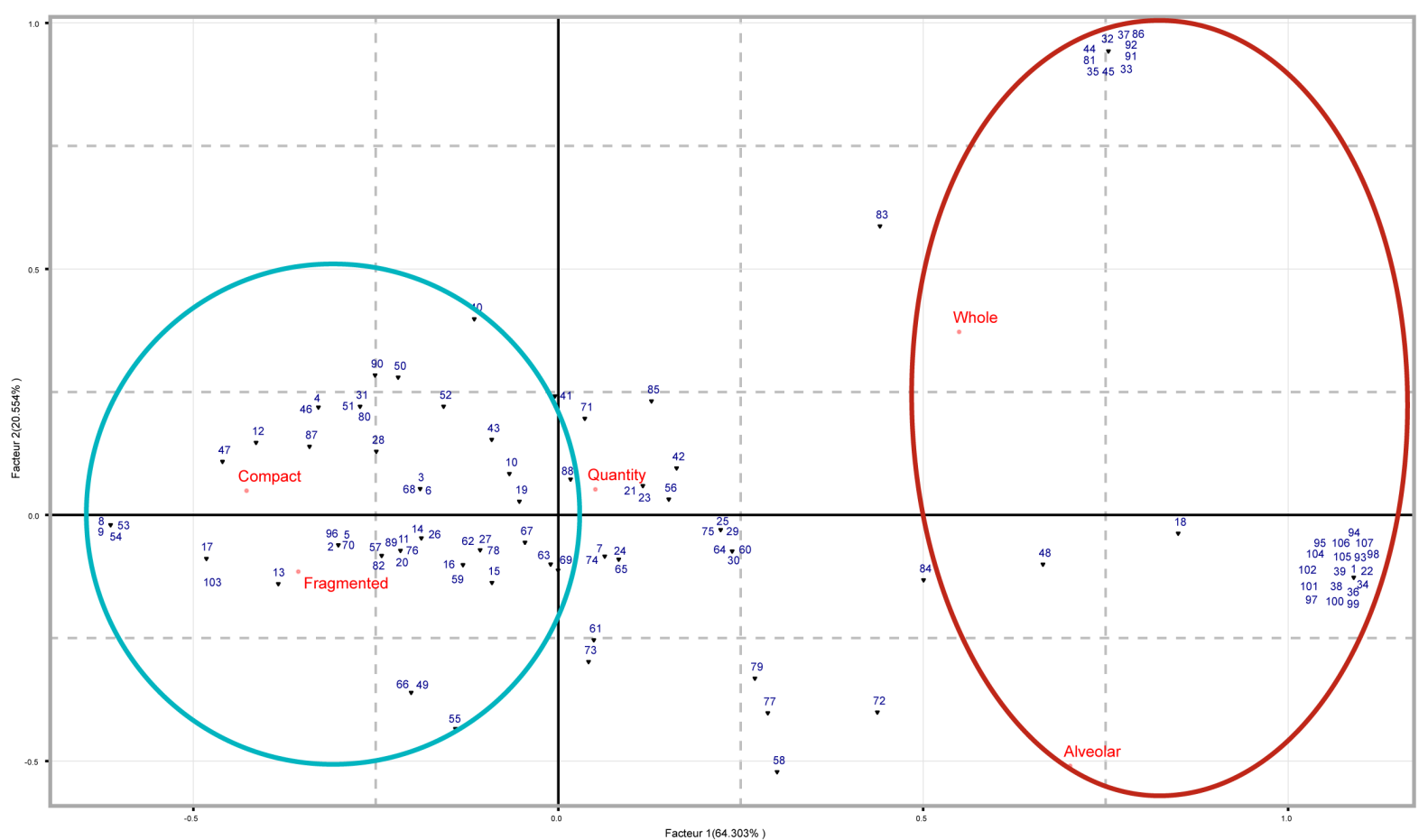

Figure 6: Correspondence analysis for organic clusters (objects) and the number of rice grains and their aspect variables). See tables 2-5 as Electronic Supplementary Material for quantitative and qualitative details.

Now, we have to determine if these broken grains are due to intentional or accidental breakage. A vast array of culinary preparations includes more or less fragmented rice grains as a main or secondary ingredient. In Rajasthan oliyâ is a porridge prepared notably with rice mixed with yoghurt or whey (Cousin 2010: 328). Rice can also be crushed, moistened, soaked or steamed to obtain a paste used for making rice cakes. Early medieval

\footnotetext{
${ }^{1}$ On the 143 organic clusters with rice remains, 30 of them could not have been described in details because of their bad state of preservation and six of them have only spikelets and/or fragments of husk. Consequently, they are not relevant for this analysis based on rice grains only.
} 
Islamic cookbooks contain recipes in which crushed rice is mixed with various ingredients (meat, wheat, pulses, vegetables, spices, sugar...) to prepare meals consumed by the upper classes in western Asia (Nesbitt et al 2010: 315-317). Pounded rice and rice flour were also used for making desserts according to the same sources. Broken grain can constitute an intermediary stage for producing rice flour also present in many recipes. In Kerala, rice flour is transformed into pancakes (dōśa) or steamed semolina balls (Abe 2007: 22). Medieval Islamic authors (compiled in Canard 1959) mention the preparation and consumption of rice bread in Middle East as a food for poor people due to its lower nutritive value. The preparation of rice bread was still observed recently in Iraq and Iran but is now of minor importance compared to bread made from wheat (Abe 2007: 20-22). Finally, Rabinot and Lafont (1910-11) have documented the use of rice flour for making cakes and sweets in the Gilan region (Iran) in the beginning of the $20^{\text {th }}$ century.

It is thus possible that the rice remains found charred in the kitchen at Mleiha corresponded to intentionally crushed rice grains that were about to be used as described above or in yet other types of preparations. Still, the presence of millet grains in the clusters indicates that a final cleaning, probably by hand picking, was still to come before cooking and consumption. Indeed, hulled grains of kodo millet can be poisonous in the case mass spores replace the full-grown grain and they should thus be eliminated prior to food preparation (de Wet 1983b).

Another explanation can be advanced taking into account the presence of weeds: instead of corresponding to intentionally broken grain the remains may represent accidentally fragmented rice that was separated from the whole grains during crop processing (Fig. 7). Indeed, rice caryopses can be fragile and thus easily break during different stages of handling. They can be naturally fissured due to variations of moisture during early and late harvesting, drying and storing (Buggenhout et al 2013, Bhattacharya 1980, 1969). Rice "chalkiness" due to the presence of starch granules loosely packed in the endosperm has been pointed out as another factor favouring breakage as well as grain dimensions, long and thin grains breaking more easily than the short ones (Buggenhout et al 2013). Different factors influencing the rice plants in the fields have also been mentioned as having an effect on the mechanical resistance of rice grains: pest infestations, temperatures, the way fertilizers are applied, etc.

Due to these different factors liable to increase the fragility of grains, breakage can easily occur during the different crop processing stages for example during dehulling or later when the grain is milled to take away the brown pericarp (the bran) and obtain white rice. The shape and materials of the tools used (mortars, pestles), the skill of the person carrying out the different operations, the mix of grain of varying dimensions etc. will have a certain importance to avoid or, on the contrary, provoke the fragmentation of grains (Abe 2007: 60-62). To slightly moisten the grains before dehulling and milling can for example reduce the breakage but if the rice is too humid the treatment becomes more difficult (Abe 2007: 60). The widespread practice of parboiling (Gariboldi 1984,1986 ) is usually also considered to reduce the breakage due to starch gelatinization inside the grain. However, if the operation is not processed properly, it can at the opposite weaken the rice grains (Buggenhout et al 2013). 
If a considerable proportion of grains break during the crop processing they can be separated from whole ones by winnowing and sieving as they are both lighter and smaller than the entire grains (Thompson 1996). In that case, they would be put aside and constitute a sort of second-rate crop. The presence of millet grains, having approximately the same weight and size as broken rice grains, could then be explained by the difficulty to separate the two during the cleaning process. This type of assemblages could be used, as described above, for different dishes and also for the preparation of alcoholic beverages (Angladette 1966: 591). The use of broken grain for fodder is a frequent practice today, particularly for feeding pigs and chicken although cattle may also be concerned (Thompson 1996: 131-132, Angladette 1966: 572-75). This is obviously not the case at Mleiha where rice seems to have been intended for human food and where it probably also was a minor or rare crop as will be discussed below.

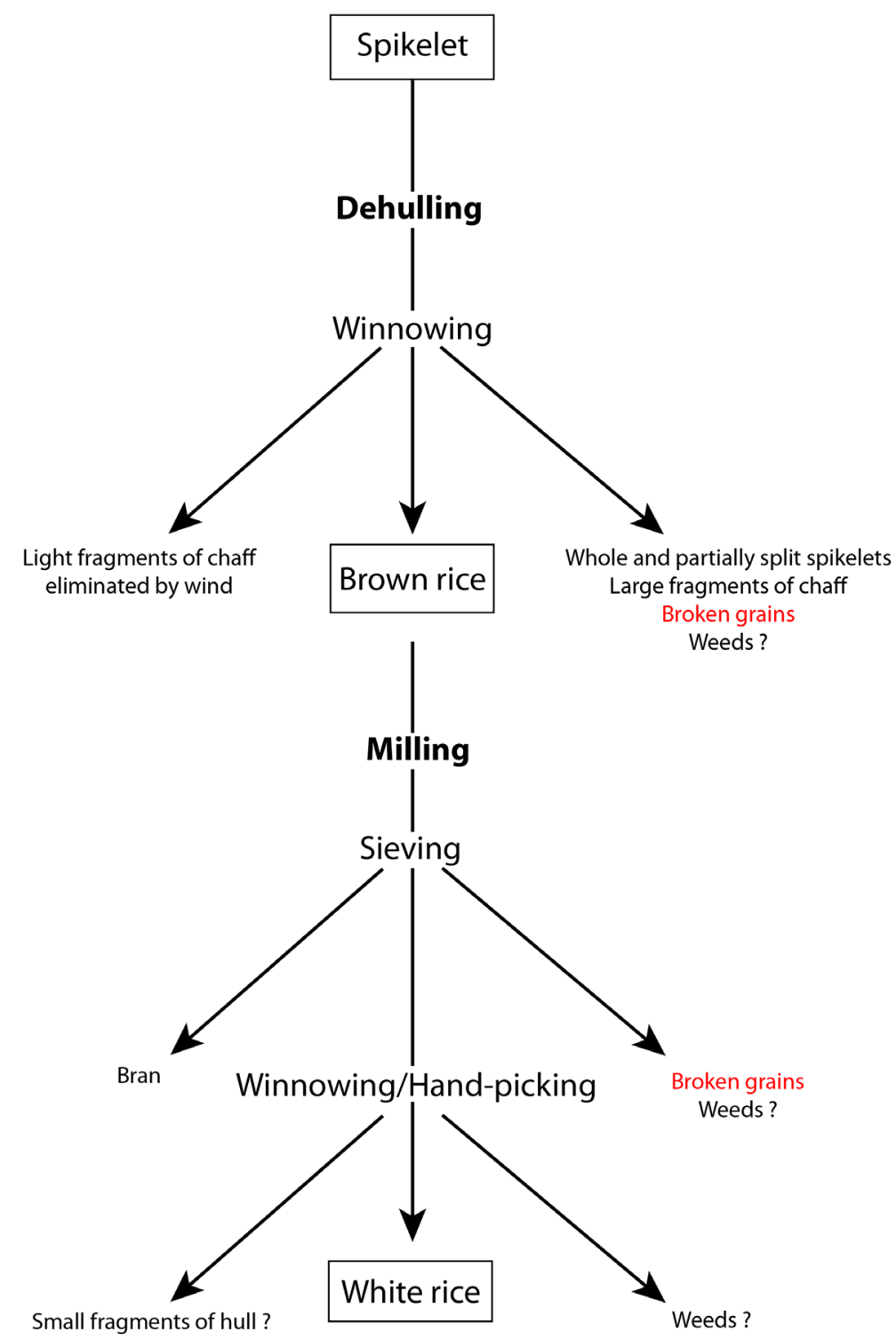

Figure 7: Simplified schema of the main crop-processing stages from the state of spikelet to white grain (framed words $=$ prime products; smaller words $=$ by-products; bold words $=$ main steps of rice-processing before consumption; italic words= description of these previous steps) (according to Thompson 1996) 


\section{Rice in the Indian Ocean trade}

Before the discovery of rice at Mleiha only two other archaeobotanical finds of the species have been reported from the Arabian Peninsula: a unique fragmented grain found in a medieval $\left(10^{\text {th }}-12^{\text {th }} \mathrm{c}\right.$. AD) storehouse at Sharma in Hadramawt (Yemen) (Dabrowski et al 2015) and several grains as well as one dessicated lemma and palea fragment from a workshop in the Islamic $\left(14^{\text {th }}-16^{\text {th }}\right.$ c. AD) harbour city of Qalhât (Sultanate of Oman) (Dabrowski et al 2018). Both of them have been tentatively interpreted as imported items as both sites were important harbours connected with remote rice-producing areas. The early finds from Mleiha raise the question of the origin of rice in eastern Arabia. Was rice imported or was it cultivated locally? The strongest argument in favour of the first hypothesis is the presence of kodo millet and little millet in the rice clusters both natives from the tropics and widely distributed in the Indian subcontinent (de Wet et al 1983a, b). They point towards an origin in India where rice was widely cultivated through all the Indian Peninsula and Sri Lanka since at least the $1^{\text {st }}$ millennium BC (Kingwell-Banham et al 2018, Fuller 2011a, Fuller et al 2010).

According to archaeological and textual evidence, several regions of the Indian sub-continent may have produced the rice found at Mleiha (Fig. 8). The $4^{\text {th }}$ century BC naturalist Theophrastus (Historia Plantarum 4, 4, 10) mentions rice as a staple food commonly planted by Indians (Amigues 2010: 144). The Periplus Maris Erythraei $(P M E)$, a manual on trade and navigation in the Indian Ocean written by a $1^{\text {st }} \mathrm{c} . \mathrm{AD}$ anonymous Greek seafarer, listed several rice producing regions in India: Parsidai and the Gulf of Terabdoi as well as Ariakê and the Gulf of Barygaza (PME 37, Casson 1989: 73 and PME 41, Casson 1989: 77). According to Casson (1989: 182-184, 197-199), they respectively correspond to the region of Sonmiani Bay and the Purali River near modern Karachi in Pakistan, and to the Gulf of Cambay, especially the region between Broach and Surat, in the modern state of Gujarat. Lymirikê in the extreme south of the Indian peninsula is not explicitly mentioned as a rice producing region even though rice is said to be exported from there. Rice was shipped from all these regions to the so-called "far-side" ports on the northern coast of Somalia (PME 14, Casson 1989: 59) and to the island of Socotra to be exchanged for other goods (PME 31, Casson 1989: 69). Claudius Ptolemy (Geographia, 7.4.1), the geographer of the $2^{\text {nd }} \mathrm{c}$. $\mathrm{AD}$, indicates also that rice was growing on the island of Taprobana identified as Sri Lanka (Stevenson 2011: 158). Rice is thus clearly a food product that was traded in the western Indian Ocean during Antiquity and whose origins were multiple. The $P M E$ does not mention the trade of rice between India and the Persian Gulf region but it has to be remembered that this text predates by two centuries the destruction of the building $\mathrm{H}$ at Mleiha and focuses on the trade linking the Egyptian Red Sea coast with India (Salles 2012, Seland 2010: 47). Other places in India not mentioned in the PME have then to be considered as potential sources of rice found at Mleiha. Still there is mention that commodities took the route directly from Barygaza to the port of Omana (PME 36, Casson 1989: 73), hypothetically identified in the Oman Peninsula as ed-Dur (Salles 2012, Seland 2010: 47) or Dibba al-Hisn (Reddy 2016). Goods and food products from India were also able to transit though intermediate ports as Sumhuran and Qanê in South Arabia and before travelling north through the Persian Gulf (PME 36, Casson 1989: 73). Indeed, the distribution of Indian pottery on south-east Arabian sites suggests several possible routes among which one that went directly from western India to the Persian Gulf and another one that passed by southern Arabia (Reddy 2016). 
In any case, there is abundant evidence of interactions with the Indian subcontinent among the finds at Mleiha. The typology, manufacture as well as petrographic analyses of cooking pots and storage vessels point to an origin in Gujarat or Mahārāshtra (Mouton et al 2012; Reddy et al 2012) while black-and-grey wares are likely to have been imported from the Indus region (Reddy 2016). The presence of cooking pots imported from the IndoPakistan region in the same contexts as rice may reflect the introduction of new cooking practices such as the boiling of rice (Reddy 2016: 68, 74).

As an imported merchandise, rice is likely to have travelled in the form of spikelets since this is the less transformed form in which it was found at Mleiha. Spikelet and husk fragments constitute the main type of rice remains found at Berenike and Myos Hormos on the Egyptian Red Sea coast, suggesting that rice arrived as spikelets to these harbour sites as well (Cappers 2006: 104-105, Van der Veen 2011: 46-47). In addition, the discovery of one desiccated spikelet of rice, dated around $96 \mathrm{AD}$, in a dump in front of the Roman fort of Didymoi tends to confirm that rice was traded under this form at this place of transit between the Red Sea and the Nile valley, in the Eastern Desert of Egypt (Tengberg 2011). Before the mechanisation of rice cultivation, rice grains used to be stored as spikelets in order to protect the grain from pests. Dehulling then took place just before consumption (Abe 2007: 69-70).

If rice was indeed imported to the Oman Peninsula from the Indian subcontinent, we may also wonder if Mleiha was the final destination for Indian imports or if such goods could have transited by the Persian Gulf in order to join terrestrial trade routes to the Near East and the Mediterranean, in parallel to the trade routes of Egypt. Commercial ways from the Indian sub-continent to the Mediterranean Sea via the Persian Gulf and the Euphrates valley, notably through Palmyrene trade, are attested (Seland 2015, 2011, Tomber 2007). Rice was one of many exotic commodities in demand by the Romans who used it mostly for medical and cosmetic purposes (Konen 1999, Warmington 1928: 219). Its use as a food is rarely mentioned and for instance in the Apicius recipes rice is mainly considered as a thickening agent for sauces (Konen 1999: 38). Its mention in the Edict on Maximum Prices (I.23) of the emperor Diocletian (284-305 AD) (Lauffer: 100-101) tends to show that it was by this time a product commonly traded within the Roman Empire (Decker 2009). The archaeobotanical finds of Oryza sativa in Europe are scarce and usually associated with specific contexts such as a $1^{\text {st }} \mathrm{c}$. AD hospital in the fort at Neuss/Novaesium in Germany where 198 charred rice grains were discovered together with medicinal plants (Knörzer 1966, 1970) or a sacrificial pit in the $2^{\text {nd }}$ c. AD temple of Isis and Magna Mater in Mogontiacum, Germany (Zach 2002). More prosaically, five rice grain fragments were found in a septic pit on the site of Mursa, a veteran colony situated in Pannonia in present-day Croatia (Reed and Leleković 2017).

Rice consumption at Mleiha attests to the importance of long distance sea trade in the Arabian-Persian Gulf in the $3^{\text {rd }} \mathrm{c}$. AD. Together with the presence of numerous cooking pots imported from India (Reddy 2016: 74) it raises the question about the identity of the inhabitants of building $\mathrm{H}$. Were they people of local origin that had adopted exotic food habits or may they even have been of Indian origin as it has been suggested for rice-eaters in the Roman harbours of the Red Sea, thought to have been Indian merchants present on the site (Cappers 2006: 105, Van der Veen 2011: 47)? 


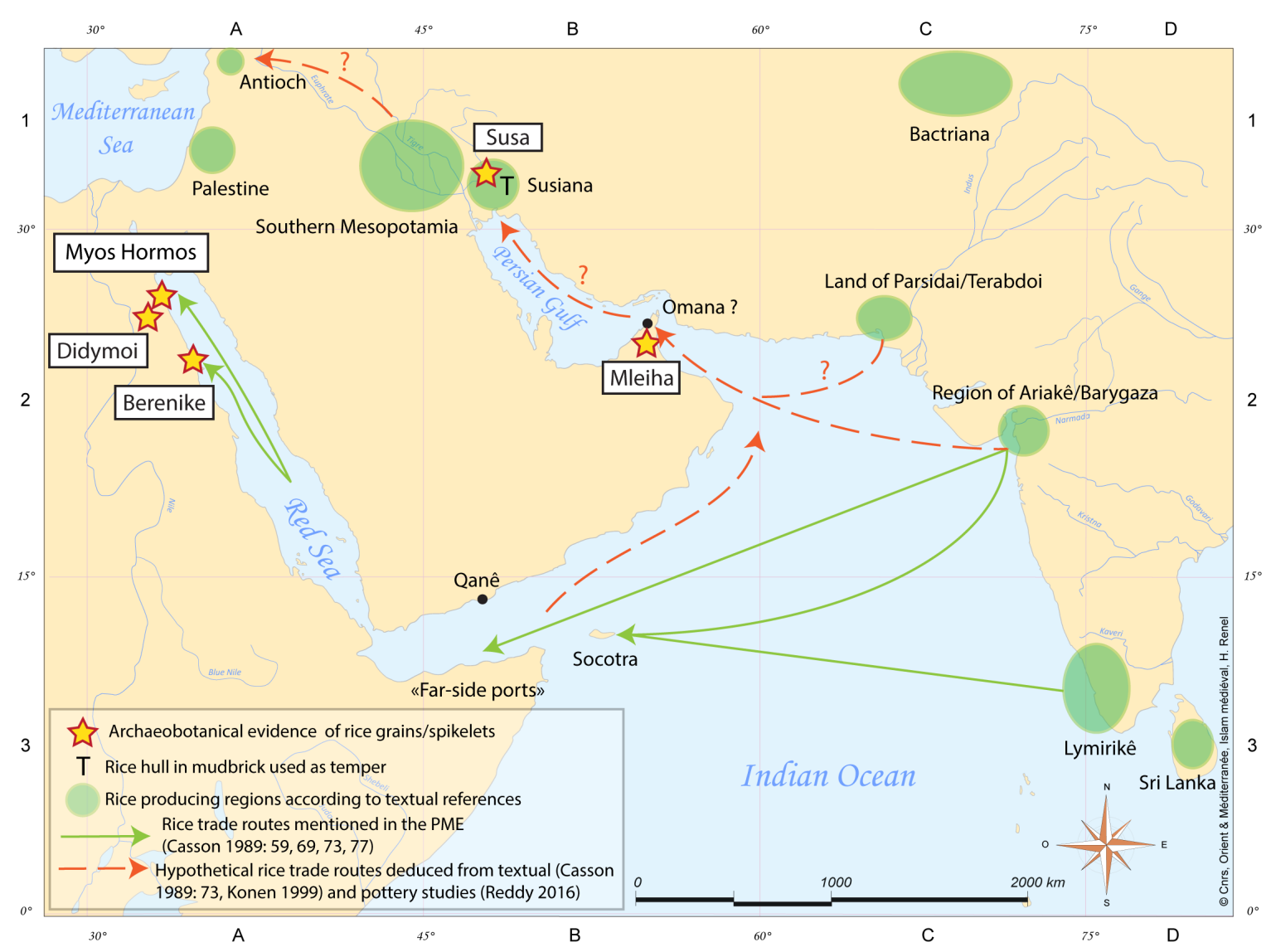

Figure 8: Archaeobotanical evidence of rice, textual references to rice producing/exporting regions and trade routes by which rice travelled in the western Indian Ocean during Antiquity.

\section{Evidence of rice growing in the Arabian Peninsula and neighbouring regions}

Even though the hypothesis of an importation of rice to the Oman Peninsula from the Indian subcontinent seems convincing, we have to bear in mind that rice is and has been grown in the Arabian Peninsula. Oryza sativa can grow on a wide array of soils, from sands to clays, and from acidic to alkaline soils although it provides higher yields on fertile heavy soils (Vergara and De Datta 1996, Kumar et al 1963: 2). Rice needs at least $42^{\circ} \mathrm{C}$ to germinate and not less than $15^{\circ} \mathrm{C}$ at night during the formation of panicles (Chalam and Venkateswarlu 1965: 94). During the growing stage the average temperatures should range between 20 and $38^{\circ} \mathrm{C}$ (Vergara and De Datta 1996). Asian rice is usually sensitive to photoperiodism but less sensitive varieties have been developed to adapt to new ecological contexts (Chalam and Venkateswarlu 1965). Water supply is also a determining factor and, while the requirements for actual upland/rain-fed rice are about $750 \mathrm{~mm}$ during the growing season (3-4 months), irrigated rice needs around $1200 \mathrm{~mm}$ (Vergara and De Datta 1996). Most of the ecological conditions needed for rice cultivation are fulfilled in eastern Arabia except sufficient rainfall (Böer 1997) that can nevertheless be supplanted by irrigation.

Rice cultivation in eastern Arabia has been recorded in textual sources since the beginning of the Islamic period (Fig. 9). Ibādī manuscripts and other texts mention rice cultivation in Arabia well before the modern period (Ubaydli 1993). Furthermore, if it seems more likely that the rice discoveries from Qalhât correspond to imported products since it is a harbour which occupied an important place within the Indian Ocean trade, a part 
of it also might come from local agriculture (Dabrowski et al 2018). Baron von Kniphausen reports on rice cultivation in the date palm groves growing on the island of Bahrain in 1754 (Floor 1984: 138). Several authors mention rice cultivation in the oasis of al-Hasa (also known as al-Hofuf) and Qatif in Saudi Arabia during the $19^{\text {th }}$ and $20^{\text {th }}$ c. AD (Potts 1994). Sadleir (1977: 52) notes during a visit to the Qatif oasis in 1819 that rice was even more important than wheat and barley while Destrées (1874) indicates that it was the second most cultivated crop in the al-Hofuf oasis. Lorimer (1908: 648-656) further states that several localities in the al-Hasa oasis were involved in rice production, as well as Dilam, former administrative centre of the al-Kharj district, in which small quantities of rice were grown alongside wheat and maize (Lorimer 1908: 460). Twitchell (1944: 384) notes that rice was still widely grown in the region in the 1940's although the production was apparently not sufficient to satisfy the local demand in the 1950's (Vidal 1955: 157 quoted by Potts 1994). Finally, another source mentions that the rice production in Oman was not enough to cover the local demand during the late $19^{\text {th }}$ c. (Hoogerwoerd 1889: 201).

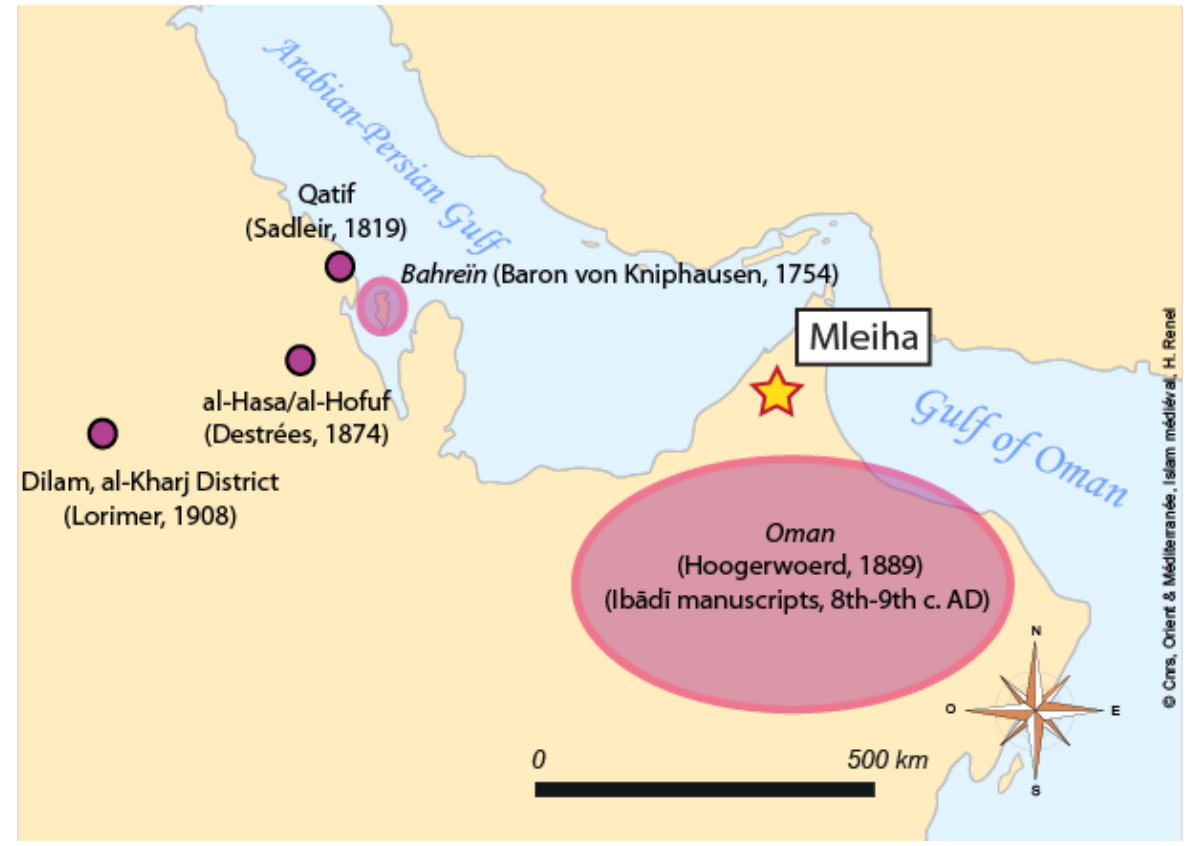

Figure 9: Medieval and earliest modern textual mentions of rice cultivation in Eastern Arabia.

Still today rice is cultivated in the eastern Province of Saudi Arabia, notably in the oasis of Al-Hasa (Al-Bahrany 2002, Zhang et al 2012). This rice, known as Hassawi rice, is a drought-tolerant variety of indica type particularly well adapted to soil salinity (Bizimana et al 2016, Zhang et al 2012, Al-Bahrany 2002) but at the same time it presents some agronomic "inconveniences" such as lodging, delayed maturity and photoperiod sensitivity. Cultivation of Hassawi rice in Eastern Saudi Arabia corroborate the historical sources by proving that it is possible to grow drought-tolerant varieties of rice in arid environments with a supply of water.

If, according to the textual sources mentioned above, rice was thus not an unknown crop in the oases of eastern Arabia at least since the Islamic period, both texts and archaeobotanical data suggest that rice was cultivated in neighbouring regions during older periods, in Susiana and Mesopotamia (Fig. 8). The most ancient reliable reference is a text in Elamite from the Persepolis Fortification Archive dated to the late Achaemenid period (late 
$6^{\text {th }}-5^{\text {th }}$ c. BC) indicating that rice was grown along the royal road between Susa and Persepolis in the Fars province (Muthukumaram 2014). The Akkadian term kurângu found in some Assyrian texts dated to the $12^{\text {th }} \mathrm{c}$. and $8^{\text {th }}-7^{\text {th }}$ c. BC has been hypothetically translated as rice (Potts 1997, Muthukumaran 2014) but its meaning is not completely certain (Jursa 1999-2000). Diodorus of Sicily (Bibliotheca historica, XIX.13.6) mentions the presence of rice in Susiana in 317/318 BC (Bizière 1975: 24). Zhang Qian, the Chinese ambassador to Central Asia during the $2^{\text {nd }}$ c. BC, notes that rice was cultivated in Mesopotamia and Parthia (Shiji Dayuan 123, quoted by Muthukumaran 2014). The discovery of 373 grains of rice on a storage room floor dated to the $1^{\text {st }} \mathrm{c}$. $\mathrm{AD}$ in the Ville Royale II in Susa (Miller 1981) as well as the presence of rice-husk impressions on mud bricks from several sites in the South Dez plain of Susiana in Iran, dated from $25 \mathrm{BC}$ to $250 \mathrm{AD}$, indicate that rice was locally grown in this region during this period (Miller 2011). Strabo ( $1^{\text {st }} \mathrm{c}$. BC/AD) (Geographia XV.1.18), possibly quoting a companion of Alexander the Great, mentions Bactriana, Susiana, Babylonia and Lower Syria as rice growing areas (Leroy 2016: 15). The Mishnah talks about the production of high-prized large rice kernels during the Roman period in Israel, possibly in the Hula Valley (Rabin 1966, Felix 1982 quoted by Zohary et al 2012, Cappers 2006: 104). Lower Syria named by Strabo (Geographia, XV.1.18) may correspond to this same production centre (Cappers 2006: 104). The Babylonian Talmud, composed mostly in Central Mesopotamia from the $3^{\text {rd }}$ to the $5^{\text {th }} \mathrm{c}$. AD, mentions at several occasions rice bread consumption both in Hozai, Khuzistan, and in the alluvial plains of Mesopotamia (Nesbitt et al 2010: 330). The Jerusalem Talmud, written around 400 AD, note the presence of rice production regions in the Levant such as the Roman Palestine or near Antioch (northern Syria) (Safrai 1994: 117-118; Konen 1999).

\section{Conclusion}

The rice remains found in building $\mathrm{H}$ at Mleiha are the earliest of their kind in the Arabian Peninsula and have raised questions on the processing and origin of rice in this part of the Middle East. While it seems indubitable that rice was consumed at the site it is unclear if the high proportion of crushed grain in the rice clusters corresponds to a culinary preference or a misshapen during treatment. The rice remains found in the courtyard, showing a higher content of chaff may correspond to rice in the process of dehulling.

Exchanges between Mleiha and the Indian subcontinent are undeniably attested by the material culture. It is likely that rice has travelled along the same trade routes to reach the site as a minor crop compared to those probably cultivated in local date palm gardens. Textual and archaeological evidence indicate rice was one of the commodities involved in the Indian Ocean trade previous to the occupation of Mleiha. The presence of typically Indian weeds, kodo millet and little millet, in the rice assemblages, would point rather to an importation than local cultivation. The consumption of rice together with the use of imported Indian potteries even raises questions on the origin of the inhabitants, of the Mleiha residence.

Still, we have also evoked the possibility of local cultivation of rice in the Arabian Peninsula and further analysis, notably by applying geochemical analysis ( $\mathrm{Sr}$ isotopes) to early rice remains from this area might answer definitively the question of its origin and, more broadly, allow us to reconstruct the history of rice trade and cultivation in Eastern Arabia. 


\section{Acknowledgments}

The authors would like to thank the Doctoral college of Sorbonne Universités who granted the first author a PhD fellowship which permit to realize the analysis; Dr. Sabah Jasim from the Department of Antiquities (Sharjah's Emirate, UAE) for the permission to export the material to the National Museum of Natural History in Paris (France); Géraldine Toutirais from the "MEB Biologie" plate-form for the SEM photographs; Pr. Dorian Q. Fuller (University College of London) with the help for identification of immature rice grains and Indian millets; Dr. Jean-Charles Ducène (EPHE) and Dr. Louise Quillien (CNRS) for their comments about textual references; the Maison du riz in Albaron (Arles, France) for the discussions about the growing conditions and the cropprocessing activities of rice; finally, the reviewer for his/her useful comments improving the paper. We are solely responsible for any errors or omissions.

\section{References}

Abe Y (2007) Le « décorticage » du riz: Typologie, répartition géographique et histoire des instruments à monder le riz. Archéologie expérimentale et ethnographie des techniques 8. Paris, Maison des sciences de l'homme

Agnoun Y, Biaou SSH, Sié M, Vodouhè RS, Ahanchédé A (2012) The African Rice Oryza glaberrima Steud: Knowledge Distribution and Prospects. International Journal of Biology 4: 158-180. DOI: $10.5539 / \mathrm{ijb} . \mathrm{v} 4 \mathrm{n} 3 \mathrm{p} 158$

Al-Bahrany AM (2002) Chemical composition and fatty acid analysis of Saudi Hassawi Rice Oryza sativa L. Pakistan Journal of Biological Sciences 5: 212-214. DOI: 10.3923/pjbs.2002.212.214

Angladette A (1966) Le riz. Paris, G.-P. Maisonneuve \& Larose

Benoist A, Mouton M, Schiettecatte J (2003) The artefacts from the fort at Mleiha: distribution, origins, trade and dating. Proceedings of Seminar for Arabian Studies 33:59-77

Bhattacharya KR (1980) Breakage of rice during milling: a review. Tropical science 22 (3):255-276

Bhattacharya KR (1969) Breakage of rice during milling, and effect of parboiling. Cereal Chemistry 46 (5):478-485

Bizimana JB, Luzi-Kihupi A, Murori RW, Singh RK (2017) Identification of quantitative trait loci for salinity tolerance in rice (Oryza sativa L.) using IR29/Hasawi mapping population. Journal of genetics 96 (4): 571-582. DOI: $10.1007 / \mathrm{s} 12041-017-0803-\mathrm{X}$

Böer B (1997) An introduction to the climate of the United Arab Emirates. Journal of Arid Environments 35 (1):3-16. DOI: https://doi.org/10.1006/jare.1996.0162

Buggenhout J, Brijs K, Celus I, Delcour JA (2013) The breakage susceptibility of raw and parboiled rice: a review. Journal of Food Engineering 117 (3):304-315. DOI: https://doi.org/10.1016/j.jfoodeng.2013.03.009

Canard M (1959) Le riz dans le Proche Orient aux premiers siècles de l'islam. Arabica 6 (Fasc. 2):113-131

Cappers RTJ (2006) Roman foodprints at Berenike: Archaeobotanical evidence of subsistence and trade in the Eastern

Desert of Egypt. Monograph 55. Los Angeles, Cotsen Institute of Archaeology, University of California Press

Casson L (ed.) (1989) The Periplus Maris Erythraei. Princeton, Princeton University press

Castillo CC (2018) Preservation bias: is rice overrepresented in the archaeological record?. Archaeological and Anthropological Sciences: 1-21. DOI: https://doi.org/10.1007/s12520-018-0717-4

Castillo CC, Tanaka K, Sato Y-I, Ishikawa R, Bellina B, Higham C, Chang N, Mohanty R, Kajale M, Fuller DQ (2016) Archaeogenetic study of prehistoric rice remains from Thailand and India: evidence of early japonica in 
South and Southeast Asia. Archaeological and Anthropological Sciences 8: 523-543. DOI: 10.1007/s12520-0150236-5

Chalam GV, Venkateswarlu J (1965) Introduction to Agricultural Botany in India. Vol. I. London, Asia Publishing House

Chang TT (2000) Rice. In: Kiple, KF, Ornelas KC (eds) The Cambridge World History of Food. Cambridge, Cambridge University Press

Charbonnier J (2015) Groundwater management in Southeast Arabia from the Bronze Age to the Iron Age: a critical reassessment. Water History 7 (1): 39-71. DOI: 10.1007/s12685-014-0110-X

Choi JY, Platts AE, Fuller DQ, Hsing (邢禹依) Y-I, Wing RA, Purugganan MD (2017) The Rice Paradox: Multiple Origins but Single Domestication in Asian Rice. Molecular Biology and Evolution 34: 969-979. DOI: https://doi.org/10.1093/molbev/msx049

Cousin Fr (2010) Les céréales au Rajasthan (Inde). In: Franconie H, Chastanet M, Sigaut F (eds.) Couscous, boulgour et polenta. Transformer et consommer les céréales dans le monde. Paris, Khartala, pp 317-340

Cuny J, Mouton M (2009) La transition vers la période sassanide dans la péninsule d'Oman: chronologie et modes de peuplement. In : Schiettecatte J, Robin C (eds.) L'Arabie à la veille de l'Islam: Bilan clinique. Orient et Méditerranée 3. Paris, De Boccard, pp 91-133

Dabrowski V (2019) Systèmes d'approvisionnement et gestion des ressources végétales en Arabie orientale aux périodes antique et islamique : approches archéobotanique et archéoentomologique, $\mathrm{PhD}$ dissertation of the National Museum of the Natural History (Paris, France)

Dabrowski V, Tengberg M, Creissen T, Rougeulle A (2018) Plant Supplying Strategies in an Islamic Omani Harbour City: Archaeobotanical Analysis from a Workshop (B39) in Qalhât (XIV ${ }^{\text {th }}-\mathrm{XVI}^{\text {th }}$ c. AD). Journal of Islamic Archaeology 5 (1): 17-38. DOI : https://doi.org/10.1558/jia.37690

Dabrowski V, Tengberg M, Guillemarre D, Bouchaud C (2015) Analyse carpologique à Sharma : production et circulation des produits végétaux. In : Rougeulle A. (ed.) Sharma : Un entrepôt de commerce médiéval sur la côte du Hadramawt (Yémen, ca 980-1180). British Archaeological Reports. London, Archaeopress, pp 417-423

Dalongeville R (1999) Mleiha : étude physique et paléoenvironnement. In : Mouton M (ed.) Mleiha I: Environnement, Stratégies de subsistance et artisanats. Travaux de la Maison de 1'Orient méditerranéen 29. Paris, De Boccard, pp 33-54

Decker M (2009) Plants and Progress: Rethinking the Islamic Agricultural Revolution. Journal of World History 20 (2): 187-206. https://doi.org/10.1353/jwh.0.0058

Destrées M (1874) Note sur l'arrondissement d'El Haça. Bulletin de la Société de Géographie de Paris, 6th sen 8: 314. Diocletian: Lauffer S (ed.) (1971) Diokletians Preisedikt. Berlin, Walter De Gruyter

Diodorus of Sicily: Bizière F (ed.) (1975) Bibliothèque Historique, Livre XIX. Paris, Les Belles Lettres

Felix Y (1982) Plants \& animals of the Mishna. Inst. for Mishna Research

Floor W (1984) The Bahrain Project of 1754. Persica XI: 129-148

Fuller DQ (2011a) Pathways to Asian civilizations: Tracing the origins and spread of rice and rice cultures. Rice 4: 7892. DOI: https://doi.org/10.1007/s12284-011-9078-7

Fuller DQ (2011b) Finding Plant Domestication in the Indian Subcontinent. Current Anthropology 52 (S4):S347-62. DOI: $10.1086 / 658900$

Fuller DQ (2017) A Millet Atlas: Some Identification Guidance, $3^{\text {rd }}$ edition 
Fuller DQ, Castillo C (2014) Rice: Origins and Development. In: Smith C (ed.) Encyclopedia of Global Archaeology. New York, Springer, pp 6339-43

Fuller DQ, Qin L (2008) Immature rice and its archaeobotanical recognition: a reply to Pan. Antiquity 82 (316)

Fuller DQ, Sato Y-I, Castillo C, Qin L, Weisskopf AR, Kingwell-Banham EJ, Song J, Ahn S-M, Etten J van (2010)

Consilience of genetics and archaeobotany in the entangled history of rice. Archaeological and Anthropological

Sciences 2: 115-131. DOI: 10.1007/s12520-010-0035-y

Fuller DQ, Weisskopf A, Castillo C (2016) Pathways of Rice Diversification across Asia. Archaeology International 19: 84-96. DOI: $10.5334 /$ ai.1915

Fuller DQ, Weisskopf A (2011) The early rice project: from domestication to global warming. Archaeology International 13: 44-51. DOI: http://doi.org/10.5334/ai.1314

Galinato MI (1999) Upland Rice Weeds of South and Southeast Asia. International Rice Research Institute

Gariboldi F (1986) L'étuvage du riz. Bulletin des services agricoles de la FAO, n56

Gariboldi F (1984) Rice Parboiling. Food and Agriculture Organization of the United Nations (ed.). Bulletin n 56.

Rome, FAO Agricultural Services

Garris AJ, Tai TH, Coburn J, Kresovich S, McCouch S (2005) Genetic Structure and Diversity in Oryza sativa L. Genetics 169: 1631-1638. DOI: https://doi.org/10.1534/genetics.104.035642

Gutaker RM, Groen SC, Bellis ES, Choi JY, Pires IS, Bocinsky RK, Slayton ER, et al (2019) Genomic History and Ecology of the Geographic Spread of Rice. BioRxiv, 748178. https://doi.org/10.1101/748178

Harvey EL, Fuller DQ (2005) Investigating crop processing using phytolith analysis: the example of rice and millets.

Journal of Archaeological Science 32 (5):739-752. DOI: https://doi.org/10.1016/j.jas.2004.12.010

Hoogerwoerd K de (1889) Die Häfen und Handelsverhältnisse des Persischen Golfes und des Golfes von Oman. Annalen der Hydrographie. Berlin 17: 89-207

Huang X, Kurata N, Wei X, Wang ZX, Wang A, Zhao Q, Zhao Y, et al (2012) A Map of Rice Genome Variation Reveals the Origin of Cultivated Rice. Nature 490 (7421): 497-501. DOI: https://doi.org/10.1038/nature11532

Jursa M (1999) Review of D.T. Potts, Mesopotamian Civilization: The Material Foundations. Archiv für Orientforschung 46/47: 290-95

Kerfant C (2015) Les vestiges textile carbonisés du site de Mleiha. 250 AD (Sharjah, U.A.E.). Msc dissertation of the Muséum national d'Histoire naturelle (Paris, France)

Kingwell-Banham E, Bohingamuwa W, Perera N, Adikari G, Crowther A, Fuller DQ, Boivin N (2018) Spice and Rice: Pepper, Cloves and Everyday Cereal Foods at the Ancient Port of Mantai, Sri Lanka. Antiquity 92 (366): 1552-70. DOI: https://doi.org/10.15184/aqy.2018.168

Knörzer K-H (1970) Römerzeitliche Pflanzenfunde aus Neuss. Berlin, Gebr. Mann

Knörzer K-H (1966) Über Funde römischer Importfrüchte in Novaesium (Neuls s/Rh.). Bonner Jahrbücher : 433-43.

Konen H (1999) Reis im Imperium Romanum: Bemerkungen zu seinem Anbau und seiner Stellung als Bedarfs-und Handelsartikel in der römischen Kaiserzeit. Münstersche Beiträge zur Antiken Handelsgeschichte 18: 23-47

Kumar LSS, Aggarwala AC, Arakeri HR, Kamath MG, Moore EN, Donahue RL (1963) Agriculture in India. Vol. II: Crops. Bombay, Calcutta, New Delhi, Madras Lucknow, London, New York, Asia Publishing House

Londo JP, Chiang Y-C, Hung K-H, Chiang T-Y, Schaal BA (2006) Phylogeography of Asian wild rice, Oryza rufipogon, reveals multiple independent domestications of cultivated rice, Oryza sativa. Proceedings of the National Academy of Sciences 103 (25): 9578-9583. DOI: https://doi.org/10.1073/pnas.0603152103 
Lorimer JG (1908) Gazetteer of the Persian Gulf,'Omān, and Central Arabia. Vol. 2. Irish Academic

Lu JJ, Chang T-T (1980) Rice in its temporal and spatial perspectives. In: Rice: Production and utilization. Westport, AVI Pub. Co., pp 1-74

Madhloom T (1974) Excavations of the Iraqi Mission at Meleha, Sharjah, U.A.E. Sumer 30:149-58

Miller N (1981) Plant Remains from Ville Royale II, Susa. Cahiers de La Délégation Archéologique Française En Iran 12:137-42

Miller N (2011) An Archaeobotanical Perspective on Environment, Plant Use, Agriculture, and Interregional Contact in South and Western Iran. Iranian Journal of Archaeological Studies 1 (2):1-8

Moody K (1989) Weeds Reported in Rice in South and Southeast Asia. International Rice Research Institute

Mouton M (2010) Mleiha et le peuplement de la péninsule d'Oman A la période Pré-Islamique Récente. In: Avanzini A. (ed) Eastern Arabia in the first millenium BC. Arabia antica 6. Rome, « L’Erma » di Bretschneider, pp 181211

Mouton M (2008) La Péninsule d'Oman de la fin de l'Age du Fer au début de la période sassanide (250 av. JC-350 ap. JC). Bar International Series 1776. Oxford: Archaeopress

Mouton M, Schiettecatte J (2014) In the desert margins the settlement process in ancient South and East Arabia. Arabia Antica 9. Roma, « L’Erma » di Bretschneider

Mouton M, Tengberg M, Bernard V, Le Maguer S, Reddy A, Soulié D, Le Grand M, Goy J. (2012) Building H at Mleiha: new evidence of the late pre-Islamic period D phase (PIR. D) in the Oman peninsula (second to midthird century AD). Proceedings of the Seminar for Arabian Studies 42:205-221

Murray SS (2007) Identifying African rice domestication in the middle Niger delta (Mali). In: Cappers RTJ (ed) Fields of change: Progress in African Archaeobotany. Gröningen, Barkhuis, pp 53-61

Muthukumaran S (2014) Between Archaeology and Text: The Origins of Rice Consumption and Cultivation in the Middle East and the Mediterranean. Papers from the Institute of Archaeology 24 (1): 1-7. DOI: http://dx.doi.org/10.5334/pia.465

Nayar NM (2014) Origins and Phylogeny of Rices. Amsterdam, Boston, Academic Press.

Nesbitt M, Simpson SJ, Svanberg I. (2010) History of Rice in Western and Central Asia. In: Sharma S (ed.) Rice: Origin, Antiquity and History. Science Publishers, pp 308-40

Overlaet B, Macdonald M, Stein P. 2016. An Aramaic-Hasaitic Bilingual Inscription from a Monumental Tomb at Mleiha, Sharjah, UAE. Arabian Archaeology and Epigraphy 27 (1): 127-42. https://doi.org/10.1111/aae.12072.

Peña-Chocarro L, Barrón Lopez E (1999) Plant remains from the site of Mleiha. In: Mouton M (ed.) Mleiha I: Environnement, Stratégies de subsistance et artisanats. Travaux de la Maison de l'Orient méditerranéen 29. Paris, De Boccard, pp. 63-69

Potts DT (1997) Mesopotamian civilization: the material foundations. London, the Athlone Press

Potts DT (1994) Contributions to the Agrarian History of Eastern Arabia II. The Cultivars. Arabian Archaeology and Epigraphy 5 (4): 236-75

Ptolemy Claudius: Stevenson EL (ed.) (2011) Geography of Claudius Ptolemy. Translated by Edward Luther Stevenson. New York, Cosimoclassics

Rabin C (1966) Rice in the Bible. Journal of Semitic Studies XI (1): 2-9

Rabino HL, D-F Lafont (1910) La culture du riz en Guilan (Perse) et dans les autres provinces du sud de la Caspienne. Annales de l'Ecole National d'Agriculture de Montpellier 10 (II): 130-164 ; 5-51 
Rao AN, Johnson DE, Sivaprasad B, Ladha JK, Mortimer AM (2007) Weed Management in Direct-Seeded Rice. Advances in Agronomy 93:153-255. DOI: https://doi.org/10.1016/S0065-2113(06)93004-1

Rao AN, Wani SP, Ahmed S, Haider Ali H, Marambe B (2017) An Overview of Weeds and Weed Management in Rice of South Asia. In: Rao AN, Matsumoto H (eds.) Weed management in rice in the Asian-Pacific region. India Asian-Pacific Science Weed Society, The Weed Science Society of Japan, Indian Society of Weed Science, pp 247-251

Reddy AL (2016) Archaeology of Indo-Gulf Relations in the Early Historic Period: The Ceramic Evidence. In: Ray HP (ed.) Bridging the Gulf: Maritime Cultural Heritage of the Western Indian Ocean. Delhi, Manohar Publishers \& Distributors

Reddy A, Attaelmanan AG, Mouton M (2012) Pots, Plates and Provenance: Sourcing Indian Coarse Wares from Mleiha Using X-Ray Fluorescence (XRF) Spectrometry Analysis. IOP Conference Series: Materials Science and Engineering 37 (1): 1-8. DOI: 10.1088/1757-899X/37/1/012010

Reed K, Leleković T (2017) First Evidence of Rice (Oryza cf. sativa L.) and Black Pepper (Piper nigrum) in Roman Mursa, Croatia. Archaeological and Anthropological Sciences 11: 271-278. DOI : 10.1007/s12520-017-0545-y

Ryan SE, Dabrowski V, Dapoigny A, Gauthier C, Douville E, Tengberg M, Kerfant C, Mouton M, Desormeau X, Noûs C, Zazzo A, Bouchaud C (submitted) The Ancient Cotton Route: strontium isotopes support a trade network between southeast Arabia and India during Antiquity. Scientific Reports.

Sadleir GF: Edwards FM (ed.). Diary of a journey across Arabia, 1819. Naples: Falcon

Safrai Ze'ev (1994) The economy of Roman Palestine. London, Routeledge

Sainz Ollero H, Garcia Anton M (1999) La végétation actuelle du territoire des Emirats Arabes Unis. In : Mouton, M. (ed.), Mleiha I: Environnement, Stratégies de subsistance et artisanats. Travaux de la Maison de l'Orient méditerranéen. Paris, De Boccard, pp 55-61

Salles J-F (2012) Le Golfe persique dans le Périple de la mer Érythrée : connaissances fondées et ignorances réelles ?. In: Boussac M-P, Salles J-F, Yon J-B (eds.) Autour du Périple de la mer Érythrée : actes du séminaire organisé les 13 et 14 décembre 2010, Lyon, Maison de l'Orient et de la Méditerranée. Topoi 11. Lyon, Maison de l'Orient et de la Méditerranée-Jean Pouilloux, pp 293-328

Sanlaville P (2000) Le Moyen-Orient arabe: le milieu et l'homme. Collection U. Paris, Armand Colin

Seland EA (2015) Palmyrene Long-Distance Trade: Land, River, and Maritime Routes in the First Three Centuries CE. In: Walter M.N., Ito-Adler J.-P. (eds) The Silk Road: Interwoven History. Cambridge, Cambridge Institutes Press, pp 101-131.

Seland EH (2014) Archaeology of Trade in the Western Indian Ocean, 300 BC-AD 700. Journal of Archaeological Research 22 : 367-402. DOI : https://doi.org/10.1007/s10814-014-9075-7

Seland EH 2011. The Persian Gulf or the Red Sea? Two axes in ancient Indian Ocean trade, where to go and why. World Archaeology 43 (3): 398-409.

Seland EH (2010) Ports and political power in the Periplus complex societies and maritime trade on the Indian Ocean in the first century AD. BAR International Series 2102. Oxford, Archaeopress

Silva F, Stevens CJ, Weisskopf A, Castillo C, Qin L, Bevan A, Fuller DQ (2015) Modelling the Geographical Origin of Rice Cultivation in Asia Using the Rice Archaeological Database. PLOS ONE 10 (9): e0137024. https://doi.org/10.1371/journal.pone.0137024 
Silva F, Weisskopf A, Castillo C, Murphy C, Kingwell-Banham E, Qin L, Fuller DQ (2018) A Tale of Two Rice Varieties: Modelling the Prehistoric Dispersals of Japonica and Proto-Indica Rices. The Holocene 28 (11): 1745-58. https://doi.org/10.1177/0959683618788634

Strabo: Leroy P-O (ed.) (2016) Géographie. Tome XII. Livre XV, L'Inde, l'Ariane et la Perse. Translated by P.-O. Leroy. Paris, Les Belles lettres

Sweeney M, McCouch S (2007) The complex history of the domestication of rice. Annals of Botany 100 (5):951-957. DOI: https://doi.org/10.1093/aob/mcm128

Tengberg M (2012) Beginnings and early history of date palm garden cultivation in the Middle East. Journal of Arid Environments, Ancient Agriculture in the Middle East 86: 139-47. DOI: https://doi.org/10.1016/j.jaridenv.2011.11.022

Tengberg M (2011) L'acquisition et l'utilisation des produits végétaux à Didymoi. In : Cuvigny H (ed) Didymoi : une garnison romaine dans le désert oriental d'Égypte I: Les fouilles et le matériel. Praesidia du désert de Berenice 4. Le Caire, Institut français d'archéologie orientale, pp. 205-14.

Tengberg M. (2008) The exploitation of Wood at Neolithic al-Buhrais18, Sharjah (E.A.U): Results of the Charcoal analysis. In: Uerpmann U, Uerpmann M, Jasim SA (eds.) The Natural Environment of Jebel Al-Buhais : Past and Present. Tübingen, Department of Culture and Information of Sharjah (E.A.U), in collaboration with Institut für Ur- und Frühgeschichte und Archäologie des Mittelalters, pp 83-96

Theophrastus : Amigues S (2010) Recherches sur les Plantes : à l'origine de la botanique. Paris, Belin

Thompson GB (1996) Ethnographic Models for Interpreting Rice Remains. In: The Excavation of Khok Phanom Di: a Prehistoric Site in Central Thailand-Volume IV: Subsistence and Environment: The Botanical Evidence (The Biological Remains, Part II). London, The Society of Antiquaries of London, Oxbow Books

Tomber R (2007) Rome and Mesopotamia - importers into India in the first millennium AD. Antiquity 81 (314):972988. DOI: https://doi.org/10.1017/S0003598X00096058

Twitchell KS (1944) Water Resources of Saudi Arabia. Geographical Review 34 (3): 365-386

Ubaydli A (1993) The agrarian economy of Oman (132-280/749-893) in Arabic sources. Journal of Islamic Studies 4 (1): $33-51$

Vergara BS, De Datta SK (1996) Oryza sativa L. In: Grubben GJH, Partohardjono S (eds.) Plant resources of SouthEast Asia $n^{\circ} 10$ : Cereals. Bogor, Prosea Foundation, pp. 106-115

Vidal FS (1955) The oasis of al-Hasa. Arabian American Oil Co., Local Govt. Relations, Arabian Research Division

Warmington EH (1928) The commerce between the Roman Empire and India. Cambridge, Cambridge University Press

Weisskopf A, Harvey E, Kingwell-Banham E, Kajale M, Mohanty R, Fuller DQ (2014) Archaeobotanical implications of phytolith assemblages from cultivated rice systems, wild rice stands and macro-regional patterns. Journal of Archaeological Science 51:43-53. DOI: https://doi.org/10.1016/j.jas.2013.04.026

Wet JMJ de, Brink DE, Prasada Rao KE, Mengesha MH 1983. « Diversity in Kodo Millet, Paspalum Scrobiculatum ». Economic Botany 37 (2):159-63.

Wet JMJ de, Prasada Rao K.E., Brink DE (1983) Systematics and domestication of Panicum sumatrense (Graminae). Journal d'agriculture traditionnelle et de botanique appliquée 30 (2):159-168 
Zach B (2002) Vegetable offerings on the Roman sacrificial site in Mainz, Germany-short report on the first results. Vegetation History and Archaeobotany 11 (1-2): 101-106. DOI: https://doi.org/10.1007/s003340200011

Zhang T, Hu S, Zhang G, Pan L, Zhang X, Al-Mssallem IS, Yu J (2012) The organelle genomes of Hassawi rice (Oryza sativa L.) and its hybrid in saudi arabia: genome variation, rearrangement, and origins. PloS one 7 (7): e42041. DOI: https://doi.org/10.1371/journal.pone.0042041

Zohary D, Hopf M,Weiss E (2012) Domestication of plants in the old world the origin and spread of domesticated plants in south-west Asia, Europe, and the Mediterranean Basin. 4th edition. Oxford, Oxford University Press 